NBER WORKING PAPER SERIES

\title{
SUDDEN STOPS, SECTORAL REALLOCATIONS, AND THE REAL EXCHANGE RATE
}

\author{
Timothy J. Kehoe \\ Kim J. Ruhl \\ Working Paper 14395 \\ http://www.nber.org/papers/w14395 \\ NATIONAL BUREAU OF ECONOMIC RESEARCH \\ 1050 Massachusetts Avenue \\ Cambridge, MA 02138 \\ October 2008
}

This paper has benefited from discussions with George Alessandria, David Backus, Michael Devereux, Patrick Kehoe, Enrique Mendoza, Carlos Végh, and the participants at the Micro Foundations of Real Exchange Rates Conference at the Carnegie Bosch Institute, the Workshop on Structural Analysis of Business Cycles in the Open Economy at the Sveriges Riksbank, the XXXI Simposio del Análisis Económico, the New Perspectives on Financial Globalization Conference at the International Monetary Fund, and seminars at Arizona State University, UCLA, MIT, and Washington University in St. Louis.

This work was undertaken with the support of the National Science Foundation under grant SES-0536970. All of the data used in this paper are available at www.econ.umn.edu/ tkehoe. The views expressed herein are those of the authors and not necessarily those of the Federal Reserve Bank of Minneapolis, the Federal Reserve System, or the National Bureau of Economic Research.

NBER working papers are circulated for discussion and comment purposes. They have not been peerreviewed or been subject to the review by the NBER Board of Directors that accompanies official NBER publications.

(C) 2008 by Timothy J. Kehoe and Kim J. Ruhl. All rights reserved. Short sections of text, not to exceed two paragraphs, may be quoted without explicit permission provided that full credit, including $\odot$ notice, is given to the source. 
Sudden Stops, Sectoral Reallocations, and the Real Exchange Rate

Timothy J. Kehoe and Kim J. Ruhl

NBER Working Paper No. 14395

October 2008

JEL No. E13,F34,F41

\begin{abstract}
$\underline{\text { ABSTRACT }}$
A sudden stop of capital flows into a developing country tends to be followed by a rapid switch from trade deficits to surpluses, a depreciation of the real exchange rate, and decreases in output and total factor productivity. Substantial reallocation takes place from the nontraded sector to the traded sector. We construct a multisector growth model, calibrate it to the Mexican economy, and use it to analyze Mexico's 1994-95 crisis. When subjected to a sudden stop, the model accounts for the trade balance reversal and the real exchange rate depreciation, but it cannot account for the decreases in GDP and TFP. Extending the model to include labor frictions and variable capital utilization, we still find that it cannot quantitatively account for the dynamics of output and productivity without losing the ability to account for the movements of other variables.
\end{abstract}

Timothy J. Kehoe

University of Minnesota

Department of Economics

1925 Fourth Street South

Minneapolis, MN 55455-0462

and NBER

and Federal Reserve Bank of Minneapolis

tkehoe@umn.edu

Kim J. Ruhl

NYU Stern School of Business

Department of Economics

44 West Fourth Street

New York, NY 10012-1126

kruhl@stern.nyu.edu 


\section{Introduction}

A sudden stop of capital flows into a developing country tends to be followed by a switch from trade deficits to surpluses, a depreciation of the real exchange rate, and decreases in output and total factor productivity. Substantial reallocation takes place from the nontraded sector to the traded sector. We construct a simple dynamic general equilibrium model and calibrate it to Mexico in 1988. We find that the model can capture the large capital inflows into Mexico following its financial opening in 1989-90, both because Mexico was initially capital poor and because its working age population was growing rapidly. When we subject the model to a sudden stop — the debt crisis in 1994-95 — it can reproduce the movements of the trade balance, the real exchange rate, and the relative price of nontraded goods. When the sudden stop is the only exogenous shock, the model cannot reproduce the observed decreases in output and TFP. We then quantitatively assess two frequently mentioned mechanisms that, at least qualitatively, could account for the decline in output and TFP, frictions in reallocating labor and variable capital utilization. We find that these mechanisms cannot account for the observed behavior of output and TFP without causing the model to generate wild movements of the trade balance, the real exchange rate, and the relative price of nontraded goods.

There have been numerous theories of why sudden stops occur; see, for example, Calvo (1988, 1998), Kaminsky and Reinhart (1999), Cole and Kehoe (2000), and Mendoza (2006). The models constructed to analyze a government's decision to default

on its debt or a foreign lender's willingness to lend typically take the effects of the default on output as exogenous. This is done to maintain tractability. In contrast, a second line of research has focused on the effects of sudden stops, taking the sudden stop as given, which is our approach. Chari, Kehoe, and McGrattan (2005), Cook and Devereux (2006), and Meza and Quintin (2007) exogenously impose sudden stops and study their effects on aggregate variables.

The empirical literature regarding sudden stops has mainly focused on aggregate variables. Calvo and Talvi (2005), Guidotti, Sturzenegger and Villar (2004), Chari, Kehoe and McGrattan (2005), and Meza and Quintin (2007) document the declines in GDP and TFP that accompany sudden stops. Our findings regarding aggregate output and productivity are similar to theirs. 
This paper focuses on the effects of a sudden stop on the disaggregated economy. When credit is restricted, we find that traded output falls by less than nontraded output and that labor and investment move from the nontraded sector to the traded sector, as is also emphasized by Tornell and Westermann (2002). We also find that the movement in the relative price of nontraded to traded goods accounts for about 20 percent of the movement in real exchange rates. We document these characteristics for the sudden stop in Mexico in 1994-95. Our findings are in line with Burstein, Eichenbaum, and Rebelo (2005) and Mendoza (2005), who study the real exchange rate depreciations that accompany sudden stops and also find that nontraded goods prices play a large role in these depreciations.

Accounting for the declines in GDP and TFP that coincide with sudden stops is challenging. Chari, Kehoe, and McGrattan (2005) show that equilibrium models with standard preferences predict not an output decrease, but an increase because of a decrease in the consumption of leisure following a reversal of the current account balance. They note that generating an output decrease requires frictions that have negative effects on output large enough to overcome the natural response to a decrease in credit.

Our analysis follows the analysis of great depressions of Cole and Ohanian (1999) and Kehoe and Prescott $(2002,2007)$ in insisting that the model generates growth accounting that matches that in the data. The growth accounting in the data indicates that most of the drop in output during the sudden stop is due to a drop in TFP. We start by explaining that the negative terms of trade shock generated by the sudden stop cannot result in drops in TFP if output is measured as real GDP in base period prices as in the data. We then extend our baseline model to incorporate two mechanisms that could generate this drop in TFP. The first is costs to adjusting the amount of labor used in production in each sector. These costs are modeled as drops in output, so the reallocation of labor between the two sectors generates a decrease in TFP. In our calibrated model, however, these costs cannot account for the observed decrease in TFP; increasing these costs beyond a certain point just results in less reallocation. The second is variable capital utilization, as in Greenwood, Hercowitz, and Huffman (1988) and Meza and Quintin (2007). To the extent that the aggregate capital stock does not change but the amount of output falls, the drop in utilization during the sudden stop appears as a 
decrease in TFP. In our model, however, while capital in the nontraded sector is underutilized during the sudden stop, capital in the traded sector is overutilized. Consequently, we find that variable capital utilization alone cannot account for the observed decrease in TFP. Combining the labor adjustment costs and variable capital utilization and pushing these frictions towards their limits, we find that the model is able to generate the observed decrease in TFP. Doing so, however, produces wild movements of the trade balance, the real exchange rate, and the relative price of nontraded goods.

Other researchers have suggested that financial constraints are important for understanding sudden stops: see, for example, Calvo (1998), Mendoza and Smith (2004), Neumeyer and Perri (2005), and Schneider and Tornell (2004). We abstract from the financial sector in our model to quantitatively assess how far a standard model can go in explaining the effects of sudden stops. As discussed above, our simple model can go a long way in accounting for the effects of a sudden stop, although the effects of a sudden stop may work through the financial sector in generating declining TFP. It is worth noting that the papers in existing literature on financial constraints and sudden stops generate decreases in output largely through a decrease in labor, however, rather than through the observed decrease in TFP.

As a final extension, we consider a specification of our model in which the economy is subject to an aggregate negative TFP shock. We find that the extended model can also account for a large share of the decline in output without distorting our ability to account for prices and trade flows. Although we do not view modeling the decrease in TFP as an exogenous shock as an appealing explanation for the observed decrease in output, we consider it an important robustness check.

\section{The 1994-95 Mexican debt crisis}

In this section, we present the properties of Mexico's opening to foreign capital in 198990 and its sudden stop in 1994-95. The successes and failures of our model depend on its ability to account for these properties. The properties that we identify are typical of sudden stop episodes in a large sample of countries; see Tornell and Westermann (2002).

Figure 1 plots Mexico's trade balance as a share of GDP. (All of the data used in this paper are available at www.econ.umn.edu/ tkehoe .) As Mexico opened its capital 
markets, the country went from being a net lender to a net borrower. In 1994, the trade deficit was 4.83 percent of GDP. In the final weeks of 1994, the sudden stop began as the government had trouble rolling over its debt. (See, for example, Kehoe 1995b.) The trade deficit became trade surpluses of 2.66 and 2.06 percent of GDP in 1995 and 1996. When the sudden stop ended in 1997, the trade balance returned to a deficit, reaching 2.14 percent of GDP in 1998. The trade balance reversal is a robust feature of sudden stops; see Guidotti, Sturzenegger, and Villar (2004).

To address the natural question of whether there were foreseeable conditions in Mexico that led to the sudden stop, consider the interest rate on Mexican dollar denominated debt. (Our measure of this interest rate is the J.P. Morgan Emerging Market Bond Index spread on Mexican Brady Bonds, computed after stripping out the collateralized principal.) We decompose this interest rate into two parts: The first is the U.S. Treasury bill rate, which is our proxy for the risk free rate. The second is the Mexico-specific interest rate spread, which is commonly used to measure the country specific interest rate premium. We find that the interest premia on Mexican debt did not increase before the crisis. In November 1994, the interest premium on Mexican debt was 4.56 percent, less than the average premium from 1991 through November 1994. Not until December, the first month of the crisis, did the premium increase to 8.90 percent and then peak at 16.37 in March 1995. We take this behavior of interest premia as evidence that the sudden stop was sudden and largely unforeseen.

The sudden stop was accompanied by a large depreciation of the real exchange rate. We define the real exchange rate for Mexico, vis-à-vis the United States, as

$$
R E R_{\text {mex }, u s, t}=N E R_{\text {mex }, u s, t} \frac{P_{u s, t}}{P_{\text {mex }, t}}
$$

where $N E R_{\text {mex,us,t }}$ is the peso-dollar exchange rate and $P_{j, t}$ is the price level in country $j$, as measured using gross output deflators. We plot the natural logarithm of the real exchange rate for Mexico in figure 2. After the opening to foreign capital, the real exchange rate appreciated; at the onset of the sudden stop, the real exchange rate depreciated by 31.49 percent from 1994 to 1995 and appreciated again as the sudden stop ended, approaching its 1994 level in 2000. 
To decompose the movements of the real exchange rate into sectoral components, we follow Stockman and Tesar (1995) and Betts and Kehoe (2001) in defining agriculture, mining, and manufacturing as the traded goods sector and construction and services as the nontraded goods sector. We rewrite (1) as

$$
R E R_{\text {mex }, u s, t}=\left(N E R_{m e x, u s, t} \frac{P_{u s, t}^{T}}{P_{m e x, t}^{T}}\right)\left(\frac{P_{m e x, t}^{T} / P_{m e x, t}}{P_{u s, t}^{T} / P_{u s, t}}\right)=R E R_{m e x, u s, t}^{T} \times R E R_{m e x, u s, t}^{N},
$$

where the price of traded goods, $P^{T}$, is the gross output deflator for agriculture, mining, and manufacturing. The first term in the decomposition measures the traded good real exchange rate. The second term in the decomposition is the price of nontraded goods in the United States relative to that in Mexico. We plot the $\log$ of $R E R^{N}$ in figure 2. When Mexico opened to foreign capital, the price of nontraded goods increased by 15.84 percent from 1988 to 1994 . This accounts for 42.24 percent of the appreciation of the real exchange rate. During the sudden stop, the price of nontraded goods decreased by 6.19 percent, accounting for 19.66 percent of the real exchange rate depreciation.

We plot real GDP per working age (age 16-54) person and total factor productivity in figure 3. The figure shows the sharp contraction of output during the first year of the sudden stop. Real GDP per working age person fell by 9.05 percent in 1995 . To measure TFP we use the aggregate production function,

$$
Y_{t}=A_{t} K_{t}^{\alpha} L_{t}^{1-\alpha}
$$

where $Y_{t}$ is real GDP, $A_{t}$ is total factor productivity, $K_{t}$ is capital, and $L_{t}$ is hours worked in period $t$. We choose a capital share of $\alpha=0.38$, in line with the estimates of García-Verdú (2005). We compute TFP as

$$
A_{t}=\frac{Y_{t}}{K_{t}^{\alpha} L_{t}^{1-\alpha}}
$$

The capital stock is constructed from investment data using the perpetual inventory method, and labor is measured as total hours worked. TFP fell by 7.89 percent in 1995 , almost matching the decline in output.

We have seen that the sudden stop was accompanied by a decline in output. The sectoral data allow us to say more. In figure 4, we plot real value added for the traded 
and nontraded sectors in Mexico. During the crisis, value added in the nontraded sector fell more than in the traded sector and then recovered at a much slower rate. This shift in production is the focus of our analysis and a key ingredient in our model below. In response to a sudden stop, the relative price of traded to nontraded goods increased, leading to a shift of resources away from the nontraded sector and into the traded sector. In the next section, we construct a general equilibrium model to help us account for the features of the data we have highlighted here.

\section{Baseline model}

We model Mexico as a semi-small open economy with perfect foresight over the paths of interest rates, TFP, population, and tariffs. Mexico is a small open economy in the sense that it takes world interest rates as exogenous, but Mexico is not small in the goods market. The price of Mexico's exported good changes in order to clear the market. In 1988 and 1989, the economy is closed to foreign capital. The economy opens to foreign capital in 1990; five years later, there is a sudden stop when foreign investors unexpectedly stop lending to the country in 1995 and 1996. From 1989 to 1993, Mexico liberalized its financial markets, internally and externally; see, for example, Kehoe (1995a). We choose 1990 as the date to model the financial opening because, as figure 1 shows, it was the first year in which Mexico had a large trade deficit. Our model combines elements of the multisector, static applied general equilibrium models used to study NAFTA (see, for example, Kehoe and Kehoe 1994), the models of Fernández de Córdoba and Kehoe (2000) and Bems and Jönsson Hartelius (2006) used to study financial liberalization in small open economies, and the models in the collection of Kehoe and Prescott (2007) used to study great depressions.

\subsection{Production}

There are 5 types of goods in the model: a domestically produced traded good, $y_{D}$, an imported good, $m$, a composite traded good, $y_{T}$ made up of the domestic traded good and imports, a nontraded good, $y_{N}$, and an investment good, $i$. All goods markets are perfectly competitive. 
The domestic traded good is produced using capital, $k_{D t}$, labor, $\ell_{D t}$, the composite traded good, $z_{T D}$, and the nontraded good, $z_{N D}$, according to

$$
y_{D t}=\min \left[z_{T D t} / a_{T D}, z_{N D t} / a_{N D}, A_{D} k_{D t}^{\alpha_{D}}\left(g^{t} \ell_{D t}\right)^{1-\alpha_{D}}\right]
$$

The producer chooses capital, labor, and intermediate inputs to minimize costs, which implies marginal product pricing conditions for capital and labor of the form

$$
r_{t}=\left(p_{D t}-a_{T D} p_{T t}-a_{N D} p_{N t}\right) \alpha_{D} A_{D} k_{D t}^{\alpha_{D}-1}\left(g^{t} \ell_{D t}\right)^{1-\alpha_{D}}
$$

and similarly for the wage $w_{t}$. Perfect competition and constant returns to scale imply that the producer earns zero profits in equilibrium:

$$
p_{D t} y_{D t}-r_{t} k_{D t}-w_{t} \ell_{D t}-p_{T t} z_{T D t}-p_{N t} z_{T N t}=0
$$

The production function for the nontraded good and the corresponding profit maximization conditions are defined analogously. We assume that productivity in each sector grows at the same, constant rate $g-1$.

The composite traded good is made up of imports and the domestic traded good using an Armington aggregator:

$$
y_{T t}=M\left(\mu x_{D t}^{\zeta}+(1-\mu) m_{t}^{\zeta}\right)^{\frac{1}{\zeta}}
$$

The imported good is the numeraire in this model, making its f.o.b. price equal to 1 , but imports are subject to domestically levied tariffs, $\tau_{t}$.

The investment good is produced using a Cobb-Douglas production function:

$$
y_{I t}=G z_{T I t}^{\gamma} z_{N I t}^{1-\gamma} .
$$

Mexico is a semi-small open economy in the sense that it faces a downward sloping demand curve for its exports. Foreign demand for the domestic traded good is

$$
x_{F t}=D_{t}\left(\left(1+\tau_{F t}\right) p_{T t}\right)^{\frac{-1}{1-\zeta}},
$$


where $\tau_{F t}$ is the tariff imposed by the rest of the world on its imports. This export demand function implies that the rest of the world has an Armington aggregator that is analogous to the one in Mexico (8). The factor $D_{t}$ grows over time, reflecting the increasing demand for the goods produced in Mexico. This growth is driven by population growth in the rest of the world as well as by technological progress.

\subsection{Households}

The economy is populated by a continuum of identical households. We differentiate the total population from the working age population. We denote the working age population $\bar{\ell}_{t}$ and match it to the evolution of the population aged 15-64 in Mexico. Letting $\tilde{n}_{t}$ denote total population, we calculate the adult equivalent population as

$$
n_{t}=\bar{\ell}_{t}+\frac{1}{2}\left(\tilde{n}_{t}-\bar{\ell}_{t}\right)
$$

to evaluate consumption per capita. We normalize the amount of time available for work by a working age person to be 1 and denote the total labor supply in period $t$ as $\ell_{t}$. Households choose this labor supply, $\ell_{t}$, consumption of traded goods and nontraded goods, $c_{T t}$ and $c_{N t}$, investment in capital $i_{t}$, and bond holdings, $b_{t}$, to maximize utility,

$$
\sum_{t=1988}^{\infty} \beta^{t}\left(\left(\varepsilon\left(\frac{c_{T t}}{n_{t}}\right)^{\rho}+(1-\varepsilon)\left(\frac{c_{N t}}{n_{t}}\right)^{\rho}\right)^{\frac{\eta \psi}{\rho}}\left(\frac{\bar{\ell}_{t}-\ell_{t}}{\bar{\ell}_{t}}\right)^{(1-\eta) \psi}-1\right) / \psi
$$

subject to the budget constraint,

$$
p_{T t} c_{T t}+p_{N t} c_{N t}+q_{t} i_{t}+b_{t+1}=w_{t} \ell_{t}+\left(1+r_{t}\right) b_{t}+r_{K t} k_{t}+T_{t}
$$

the law of motion for capital,

$$
k_{t+1}=k_{t}(1-\delta)+i_{t}
$$

the appropriate nonnegativity constraints, initial conditions for the capital stock, $\bar{k}_{1988}$, and bond holdings, $\bar{b}_{1988}$, and a condition on bond holdings, 


$$
b_{t} \geq-n_{t} g^{t} B
$$

where $B$ is chosen large enough so that this constraint rules out Ponzi schemes but does not otherwise bind in equilibrium.

If the economy is open to foreign capital, so that consumers can buy and sell foreign bonds, the first order conditions for $b_{t}$ and $k_{t}$ imply the arbitrage condition

$$
1+r_{t}=\left((1-\delta) q_{t}+r_{K t}\right) / q_{t-1}
$$

When the economy is closed to foreign capital, the interest rate $r_{t}$ is endogenously determined by the return to domestic capital and payments on debt, $-b_{t}$, are made at an exogenous rate $\bar{r}_{t}$. When the economy is open to foreign capital $r_{t}=r^{*}+\sigma_{t}$, where the world interest rate is constant at $r^{*}$ and the interest rate premium is $\sigma_{t}$. Bonds are denominated in units of the imported good, which implies that a real depreciation makes debt more expensive in terms of domestically produced goods. Households receive a lump sum transfer, $T_{t}$, of tariff revenues collected on imports. In our calibration, we also impose a tax on net capital income in 1989 to account for the low level of investment in 1988 relative to future periods, replacing $r_{K 1989}$ in the budget constraint (13) by $\left(1-\tau_{K 1989}\right) r_{K 1989}$. The revenue from this tax is also rebated in the lump sum transfer $T_{1989}$.

\subsection{Market clearing and equilibrium}

The market clearing conditions are

$$
\begin{gathered}
x_{D t}=y_{D t} \\
c_{N t}+z_{N I t}+z_{N D t}+z_{N N t}=y_{N t} \\
c_{T t}+z_{T I t}+z_{T D t}+z_{T N t}+x_{F t}=y_{T t} \\
i_{t}=y_{I t} \\
k_{D t}+k_{N t}=k_{t} \\
\ell_{D t}+\ell_{N t}=\ell_{t} .
\end{gathered}
$$


The balance of payments condition is

$$
m_{t}+b_{t+1}=p_{T t} x_{F t}+\left(1+r_{t}\right) b_{t} .
$$

Here $p_{D t} x_{F t}-m_{t}=b_{t+1}-\left(1+r_{t}\right) b_{t}$ is the balance of trade and $b_{t+1}-b_{t}=p_{T t} x_{F t}-m_{t}+r_{t} b_{t}$ is the balance of payments.

In the model without a sudden stop, an equilibrium consists of sequences of all relevant variables such that households maximize utility subject to the budget constraints and other constraints, the prices and quantities satisfy the profit maximization conditions for producers, the rest of the world demands Mexican exports according to its demand function, the market clearing conditions and balance of payments conditions hold, and tariff and tax revenues equal the lump sum rebate in each year. The economy is closed to foreign capital flows in 1988 and 1989, and we assume that net foreign bond holdings stay constant at $b_{1990}=b_{1989}=\bar{b}_{1988}$ and that payments on the debt $-b_{t}$ are made at the rate $\bar{r}_{1990}=\bar{r}_{1989}=\bar{r}_{1988}$. In the model with a sudden stop in 1995, the equilibrium is that of the model without the sudden stop up until 1995. The equilibrium in 1995 and thereafter is that of a model starting in 1995, with initial capital and foreign bond holdings given by the model without a sudden stop, but in which the economy is closed to foreign capital flows in 1995 and 1996, and in which net foreign bond holdings stay constant at $b_{1997}=b_{1996}=\bar{b}_{1995}$ and that payments on the debt $-\bar{b}_{t}$ are made at the rate $\bar{r}_{1997}=\bar{r}_{1996}=r_{1995}$. In other words, we model the equilibrium as one of perfect foresight, except that the sudden stop is completely unexpected.

The period in the model is one year. To compute the equilibrium of the model, we truncate the model after 100 years, requiring the equilibrium to converge to a balanced growth path in 2088. See Conesa, Kehoe, and Ruhl (2007) for information about how to do this sort of computation, including an algorithm.

\section{Calibration}

As in the multisector, static applied general equilibrium models analyzed by Kehoe and Kehoe (1994), most of the model's parameters are calibrated so that the equilibrium of the model in 1988 replicates the data in an input-output matrix. Table 1 presents such a 
matrix for Mexico in 1988. We take the United States to stand in for the rest of the world; in 1994, the United States accounted for 68.97 percent of total merchandise imports to Mexico and 84.22 percent of total merchandise exports from Mexico.

The dynamic nature of the model makes several other features of the calibration of crucial importance. The initial capital stock $\bar{k}_{1988}$ and the initial tax on capital income $\tau_{K 1989}$ are calibrated so that Mexico is capital poor. (We could impose a tax $\tau_{K 1988}$, but it is irrelevant since $\bar{k}_{1988}$ is fixed and tax revenues are rebated to consumers.) In 1990, Mexico not only opens itself to foreign capital flows, but also undertakes reforms to domestic financial markets that we model as an elimination of $\tau_{K 1989}$. Also of crucial importance to the dynamics of the model are the calibration of the paths for working age population and adult equivalent population, $\bar{\ell}_{t}$ and $n_{t}$, and the growth in these variables compared to growth in the United States, captured by $D_{t}$. When Mexico opens to capital flows, it borrows, not only because it is capital poor, but also because it has a rapidly growing working age population. The rapidly growing population causes this borrowing to persist over time. The interest premia $\sigma_{t}$ play an important role in determining the path of borrowing, in particular, slowing it initially. Of less importance are the paths for Mexican tariffs $\tau_{t}$ and U.S. tariffs $\tau_{F t}$. We summarize the baseline model's calibration in table 2 .

\subsection{Production parameters}

The parameters in the production functions for the domestic traded and nontraded goods are computed from the input-output matrix in table 1. We choose quantities for the model so that all prices and the wage rate are equal to 1 in 1988. Quantity units have been normalized so that GDP is 100 . Since prices have been normalized to 1 , this means that every quantity is expressed as a percent of 1988 GDP.

Using the profit maximization conditions for producers, we calibrate the parameters of the production functions so that the quantities in the input-output matrix are equilibrium values in 1988. Consider, for example, the production function for the investment good (9). The first order conditions for profit maximization imply that 


$$
\frac{p_{T 1988}}{p_{N 1988}}=\frac{\gamma Z_{N 11988}}{(1-\gamma) Z_{T 11988}} .
$$

Setting $p_{T 1988}=p_{N 1988}=1$ and plugging in the values $z_{T 11988}=10.158$ and $z_{N 11988}=12.403$, we obtain $\gamma=0.450$, which is in line with the estimates of Bems (2008). We calculate

$$
G=\frac{y_{I t}}{Z_{T I t}^{\gamma} z_{N I t}^{1-\gamma}}=\frac{22.561}{10.158^{0.450} 12.403^{0.550}}=1.990
$$

To calibrate the Armington aggregator, we must choose the elasticity of substitution between imports and domestic traded goods, $1 /(1-\zeta)$. As discussed in Ruhl (2008), there is debate over this elasticity since business cycle models tend to imply low elasticities while analysis of trade policy episodes suggests elasticities much higher. We choose $1 /(1-\zeta)=2$. The first order conditions for profit maximization imply that

$$
\frac{\mu}{1-\mu}=\frac{p_{D 1988}}{1+\tau_{1988}}\left(\frac{m_{1988}}{x_{D 1988}}\right)^{\zeta-1} .
$$

With prices normalized to 1 in the base year, $\mu$ can be calculated using the data on imports and domestic traded goods. The parameter $M$ is chosen so that the output of the composite traded good in equation (8) is that observed in the data.

We choose the growth rate $g-1$ to be 2 percent, which is the growth rate of U.S. GDP per working age person during the twentieth century, and which Kehoe and Prescott (2007) argue is the growth rate implied by technological progress. Our results indicate that this value may be a little too high for Mexico, at least during 1988-2000.

We set $r_{1988}=0.1574$. This value comes from setting $r^{*}=0.0400$ and from our data on interest premia and is similar to that obtained by the calculation of how much of the income difference between Mexico and the United States can be accounted for by differences in capital stocks by Kehoe (1995b). Given that depreciation was 10.566 percent of GDP in 1988 while gross capital earnings were 37.295, we can calculate

$$
k_{1988}=\frac{37.295-10.566}{0.1574}=169.817
$$




$$
\delta=\frac{10.566}{169.817}=0.062
$$

\subsection{Household parameters}

We set the intertemporal elasticity of substitution $1 /(1-\psi)=0.5$. Following McGrattan and Prescott (2003), we set the world interest rate in the balanced growth path $r^{*}=0.040$. Requiring this interest rate to be consistent with balanced growth implies that $\beta=g^{1-\psi} /\left(1+r^{*}\right)=0.987$. Following Kravis, Heston, and Summers (1982) and Stockman and Tesar (1995), we set the elasticity of substitution between traded and nontraded goods in consumption as $1 /(1-\rho)=0.5$. The first order conditions from the household's problem yields the condition

$$
\frac{\varepsilon}{1-\varepsilon}=\frac{p_{T 1988}}{p_{N 1988}}\left(\frac{c_{T 1988}}{c_{N 1988}}\right)^{1-\rho},
$$

which can be used to calibrate $\varepsilon$. Given the value of $\ell_{t} / \bar{\ell}_{t}=0.267$ from the data set of Bergoeing, Kehoe, Kehoe, and Soto (2002), we can similarly calibrate $\eta$.

In 1989, Mexico ran a trade surplus of 1.390 percent of GDP. We set the initial stock of bonds held by the consumer, $\bar{b}_{0}$, so that the model replicates this statistic. To account for the level of investment in 1989 in the input-output matrix, we set $\tau_{K 1989}=0.201$ in the baseline numerical experiment. Since the return to capital in 1989 varies in our other numerical experiments, we need to recalibrate $\tau_{K 1989}$ in each one.

\subsection{Exogenous processes}

To account for any changes that might be due to the North American Free Trade Agreement, we include falling tariffs in the model. We model Mexican tariffs on U.S. goods as being 10.00 percent until 1994, at which time they fall to 5.00 percent. From 1994 to 2004 the tariff rates fall by 0.50 percentage points a year, until they are 0. U.S. tariffs on Mexican goods are 3.00 percent until 1994, at which time they fall to 1.50 percent. From there, tariffs fall by 0.15 percentage points per year until they reach 0 in 
2004. Both tariffs remain at 0 forever after 2004. (See Kehoe 1995a for information on the Mexican trade reform.)

As can be seen in figure 5, the interest premium on Mexican debt fell from 11.74 percent in December of 1990 to 4.56 percent in November of 1994. These higher interest rates are usually regarded as country specific risk premia, and the gradual elimination of these premia reflect the idea that Mexico gradually gained credibility as it instituted structural changes. Since we do not model the structural changes taking place in the Mexican economy, we take as exogenous a time varying interest premium on the rate at which Mexico can borrow from the rest of the world. This approach is also used in Bems and Jönsson Hartelius (2006) and Cook and Devereux (2006).

We use the J.P. Morgan Emerging Market Bond Index spread on Brady Bonds as our measure of the Mexican interest premia, as discussed previously in section 2. The premia spike in 1995, reflecting the increase in the perceived country risk following the sudden stop. Since the post-1994 premia would not have evolved in the same way if the country had not experienced the crisis, we assume that agents believed the path of interest premia to be that same as in the data up to 1994, and that the premia gradually decline to zero by 2005 . These anticipated premia are graphed in figure 5. Once the sudden stop has occurred, agents perfectly foresee the path of interest rates that are the same as in the data until 1998, at which point they gradually decline to zero by 2015 . Our data start in 1991, and we assume that the premia for 1988-90 are the same as in 1991.

Population growth rates for the United States and Mexico are exogenous to the model. These population growth rates are constructed from the observed data for 19882005 and from population projections made by the United Nations for 2005-50. (See the data appendix available at www.econ.umn.edu/ tkehoe.) We determine the series for $D_{t}$ using the calibrated value for $D_{1988}$, the growth factor $g=1.020$, and the growth of working age population in the United States. It is worth noting that the constant interest rate $r^{*}=0.040$ is not consistent with varying population growth, but we do not intend to carefully model the dynamics of U.S. interest rates.

In the formula for the real exchange rate in (1) and that for the relative price of nontraded goods in (2), we need a series for the relative price $P_{u s, t}^{T} / P_{u s, t}$. We take this 
series from the data. Given our modeling of Mexico as a semi-small open economy, this series plays no role in our model, only in the comparison of the results with the data.

\section{Results}

Before subjecting the model to a sudden stop, it is useful to study briefly the model without a sudden stop. When Mexico opens to capital flows, its capital-output ratio is lower than it will be in the balanced growth path. Figure 6 plots the capital-output ratio for the model without a sudden stop. Mexico accumulates capital until it reaches the balanced growth path. To smooth consumption over the transition, the country borrows from abroad initially, running trade deficits. The deficits switch to surpluses as the country pays back the debt.

\subsection{Baseline model}

When the sudden stop occurs, the traded good, whose use was being financed by a trade deficit, becomes relatively scarce and its price increases. Since the sudden stop is unexpected, capital and labor are not efficiently allocated across the two sectors, so they are reallocated from the nontraded to the traded good sector. The results of the baseline numerical experiment are summarized in figure 7 and table 3 .

Figure 7(a) plots the trade balance in the model and the data. As in the graphs that follow, the data are plotted as a solid line and the model results are plotted as a dashed line. The model does a good job of reproducing the shape of the trade balance. The trade balance goes negative when the country opens to capital flows and sharply reverses when the sudden stop occurs. As the sudden stop ends, the trade balance returns to a deficit, though it takes longer in the model, not turning negative until 2002. In the model, Mexico does not return to borrowing immediately following the sudden stop because the interest premia, shown in figure 5, remain high until 1999.

Figure 7(b) plots the real exchange rate. The real exchange rate in the model does not appreciate as quickly as in the data, but it displays the same sharp depreciation as the data during the sudden stop. In the model, the real exchange rate depreciates by 41.36 percent compared to the 31.49 percent in the data. As the sudden stop ends, the real exchange rate appreciates, as in the data, although less so. During the sudden stop, the 
price of nontraded goods in Mexico decreases. This can be seen in figure 7(b), which displays the relative price of nontraded goods, $-\log R E R^{N}$. From 1994 to 1995 the price of nontraded goods in the model falls by 6.10 percent, compared to 6.19 percent in the data.

Mendoza (2000) and others show that changes in $R E R^{T}$ and those in $R E R^{N}$ are negatively correlated in periods of managed exchange rates and positively correlated otherwise. The period 1988-2000 straddles a regime change; Mexico allowed the peso to float starting in 1995. In the data, the correlation between first differences in $R E R^{T}$ and those in $R E R^{N}$ is -0.30 for $1988-94$ and 0.79 for $1995-2000$. Our real model cannot address issues of nominal exchange rate management. Nevertheless, it captures 36 percent of the difference between the two correlations. The relevant correlation is 0.54 for 1988-94 and 0.93 for 1995-2000, suggesting that the relevant differences between the two subperiods involve more than just differences in exchange rate management.

Our model departs from the small open economy framework by assuming that the terms of trade, which are plotted in figure 7(d), are not exogenous. The terms of trade in the model depreciate much more than those in the data; the boom in exports that accompanies the sudden stop drives the traded good price too low relative to the data. Some of this is a result of model specification. In the model, all domestically produced traded goods are exported, in contrast to a model where the good that is exported differs from the basket of all traded goods. Data that are more closely related to our model's terms of trade are the traded good real exchange rate, $R E R^{T}$. Figure $7(\mathrm{~d})$ shows that the depreciation in $R E R^{T}$ is larger than that in the terms of trade and is almost identical to that in model. In section 5.5, we study a model with exogenous terms of trade.

Much of the model's failure to capture the speed at which the trade balance returned to a deficit and the real exchange rate appreciated is due to the high interest premia in 1998 and 1999, due to the Asian crisis and the Russian crisis. A model in which the jump in these premia is sudden and unforeseen could do better in capturing the trade deficits and the real exchange rate depreciation. So could a model in which a period is a quarter rather than a year - notice that, in figure 5, the interest premia are not high during all of 1998 or 1999. 
Figure 7(c) shows that the model reproduces the shift of production from the nontraded to the traded sector, but it fails to capture the falling output in the traded sector. Output in the nontraded sector does fall, but not by as much as it does in the data. Figure 7(f) compares GDP per working age person and TFP in the model and in the data. The model does a poor job of generating the decline in output and TFP that we see in the data. We discuss this feature of the model in detail in section 6.

The qualitative features of our results come from having two goods, one of which is nontraded, and an initial capital stock that is below its balanced growth levels. The quantitative features of our results are determined by many factors, but the most important two are the specifications of the interest rate premia and of the population growth rates. In extensive sensitivity analysis not reported here, we have found that it is these sorts of factors - those related to the model's dynamics - that are most important to our results. The specifications of the static features are far less important. When we model the combination of intermediate goods and value added in the production functions for goods in (5) as being Cobb-Douglas rather than fixed proportions, for example, we find that the results change by negligible amounts.

\subsection{Model without interest rate premia}

To see how the interest premia determine our results, we consider a model without them. We recalibrate parameters to match the same targets as in the baseline model. Table 3 summarizes the model's results. The results for the model without interest premia are qualitatively similar to those of the baseline model, but are far more volatile, as can be seen in figure 8(a). Without the gradually falling premia, Mexico immediately runs large trade deficits, quickly accumulating debt. When the sudden stop occurs, the current account reversal is much larger than in the baseline model. When the sudden stop ends, the country immediately returns to borrowing.

Immediately being able to borrow at the world interest rate leads to a larger movement out of the traded good sector in the early 1990s. This increases the price of the domestic traded good and drives the sharp real exchange rate appreciation in figure 8(b). During the sudden stop, the real exchange rate depreciates even more so than in the baseline model as the larger debt that has been accumulated requires larger interest 
payments, which brings about a larger boom in exports. As is clear from table 3 , the interest premia have little effect on the aggregate quantities.

\subsection{Model without population growth}

Mexico is experiencing a demographic transition; the population of age 15-64 is growing faster than the total population. The growing working age population increases the demand for capital, creating a greater incentive to borrow abroad. In this section, we consider the baseline model, but without population growth. The results are summarized in table 3. Figure 9(a) plots the trade balance. It is clear from the figure that population growth is a key driver of the model. Without population growth, Mexican households quickly accumulate enough capital to make borrowing unnecessary, which can be seen by comparing figure 9(b) to 7(f). In fact, after the sudden stop, agents would like to lend to the rest of the world in order to take advantage of the high interest rate premia in 1998.

\subsection{Model without trade liberalization}

During the period we study, Mexico was liberalizing its trade, both unilaterally and through the North American Free Trade Agreement. To capture this in the baseline model, we have tariffs falling over time, as described in section 4 . We test the sensitivity of the model to this assumption by solving the model with tariffs set to zero in every period. The recalibration to 1988 requires us to modify the input-output matrix to eliminate the initial tariff. The results of this model are summarized in table 3 . Besides speeding up import growth in the early 1990s and slightly increasing the overall volatility of our results, removing trade liberalization has little effect.

\subsection{Exogenous terms of trade}

In the baseline model, Mexico faces an export demand function (10). This specification, although standard in static applied general equilibrium trade models, is a departure from the common assumption that the export price is an exogenous variable in open economy macro models. The terms of trade in the baseline model depart significantly during the sudden stop, as was seen in figure 7(d). In this version of the model, we allow the terms of trade to be endogenous in all periods except for 1995 . We adjust $D_{t}$, the scale 
parameter in the export demand function, (10), in 1995 and thereafter by the factor of 1.638 , so that the increase in the terms of trade in the model is exactly the same as it is in the data. This is an increase in U.S. demand for Mexican exports resulting from NAFTA, but not captured by our Armington specification (10). We can think of Ruhl (2008) as providing a justification, but we should note that we assume that the increase is not foreseen. The results are summarized in table 3 and figure 10 .

In table 3 , the results from the model with exogenous terms of trade differ from the baseline results in two significant ways: during the sudden stop, the real exchange rate does not depreciate enough, and imports increase. The smaller depreciation of the real exchange rate is, again, the product of the model specification; the terms of trade are $R E R^{T}$, so dampening the terms of trade dampens $R E R^{T}$, which dampens the response of the real exchange rate. Given the specification that the exported good is the same as the traded good, the model accounts either for the terms of trade or the real exchange rate, but not both. To do both, we would need to model exports as having a different price than the basket of all traded goods.

\section{Output and productivity}

The baseline model can account for the trade balance, real exchange rates, and relative prices. Yet, as seen in figure 7(f), it cannot reproduce the output dynamics in Mexico. We decompose the growth of GDP using an accounting framework based on the neoclassical growth model. Following Hayashi and Prescott (2002) and Kehoe and Prescott (2002), we write the production function in (3) in terms of output per working age person and measures of factor inputs that are constant along a balanced growth path,

$$
\frac{Y_{t}}{N_{t}}=A_{t}^{\frac{1}{1-\alpha}}\left(\frac{K_{t}}{Y_{t}}\right)^{\frac{\alpha}{1-\alpha}} \frac{L_{t}}{N_{t}},
$$

where $N_{t}$ is the working age population. We take the logarithm of (30) and use it to decompose changes in output per working age person into changes in labor, capital accumulation, and TFP.

The growth accounting is presented in table 3. In 1988-94 output per working age person grew at a rate of 1.06 percent per year, more than half of which came from an 
increase in hours worked. During the sudden stop, output per working age person fell by 8.89 percent, the TFP factor, $A_{t}^{\frac{1}{1-\alpha}}$, fell by 12.69 percent, the capital factor, $\left(K_{t} / Y_{t}\right)^{\frac{\alpha}{1-\alpha}}$, increased by 6.18 percent, and hours worked per working age person fell by 2.38 percent. Since the end of the crisis, output per working age person grew at 3.16 percent per year, mostly accounted for by growth in TFP and hours worked. Our results are similar to those in Meza and Quintin (2007) who also use a growth accounting framework to study sudden stops in Mexico and countries affected by the Asian crisis in the late 1990s.

Growth accounting makes it clear that any theory that hopes to explain the drop in output following a sudden stop must also deliver a sharp decline in aggregate TFP. Our growth accounting provides discipline - as in the papers in Kehoe and Prescott (2007) - to our search for a model of output dynamics. In what follows, we consider candidate explanations for the output drops that have been suggested in the literature: the increased price of intermediate inputs, frictions in the labor market, variable capital utilization, and quasilinear utility functions.

In analyzing the results from our model, we do growth accounting using equation (30), treating the data generated by our model just as the Mexican statistical agency, the Instituto Nacional de Estadística, Geografía, e Informática, and we treat the data from Mexico. We calculate real output, $Y_{t}$ in equation (30), as GDP in 1993 base year prices:

$$
\begin{aligned}
Y_{t}= & \left(p_{D 1993}-a_{T D} p_{T 1993}-a_{N D} p_{N 1993}\right) A_{D} k_{D t}^{\alpha_{D}-1}\left(g^{t} \ell_{D t}\right)^{1-\alpha_{D}} \\
& +\left(p_{N 1993}-a_{T N} p_{T 1993}-a_{N N} p_{N 1993}\right) A_{N} k_{N t}^{\alpha_{N}-1}\left(g^{t} \ell_{N t}\right)^{1-\alpha_{N}}+\tau_{1993} m_{t}
\end{aligned}
$$

Similarly, we calculate the investment that goes into calculating the capital stock in equation (30) by dividing investment expenditures in current prices $p_{T t} z_{T I t}+p_{N t} z_{N I t}$ by the GDP deflator formed by dividing GDP in current prices by constant prices in equation (31). Notice that the resulting measure of the capital stock differs from that in the model in equations (9) and (14). This is true especially in the model with variable capital utilization and allows the model to account for some of the changes in measured TFP. 


\subsection{Imported intermediate goods}

At the onset of the sudden stop, the terms of trade turned against Mexico. Consequently, the exports that Mexico was producing now bought fewer imported intermediate goods. Thus, negative terms of trade shocks have an effect similar to a negative TFP shock. Was the deterioration in the terms of trade important for understanding Mexico's output and TFP? Quantitatively, the answer is no. The terms of trade in the baseline model depreciate - even more so than in the data - yet there is no noticeable drop in either output or TFP. Not only do terms of trade changes not quantitatively affect output in the model, but, when output is measured as real GDP in (31), the terms of trade shocks cannot qualitatively effect output either. This is because the terms of trade enter GDP calculations as a price. As discussed in Kehoe and Ruhl (2008), the national accounting procedures imply that terms of trade shocks can rarely affect real GDP.

\subsection{Labor frictions}

In this section, we introduce a cost to firms that adjust their labor inputs. During the sudden stop the economy wants to move workers from the nontraded sector to the traded sector. In doing so, some output is lost. Qualitatively, this creates a drop in GDP and a drop in TFP. In this section, we assess the quantitative relevance of this friction.

The model is identical to the baseline model except that firms lose some output if they adjust employment. The adjustment function takes the quadratic form used by Sargent (1978). The production function for domestic traded goods becomes

$$
y_{D t}=\min \left[z_{T D t} / a_{T D}, z_{N D t} / a_{N D}, A_{D} k_{D t}^{\alpha_{D}}\left(g^{t} \ell_{D t}\right)^{1-\alpha_{D}}\right]-g^{t} \theta\left(\frac{\ell_{D t}}{\ell_{D t-1}}-1\right)^{2} \ell_{D t-1} .
$$

The production function for nontraded goods changes similarly. We assume that the costs grow at the same rate as productivity, $g-1$, so that the costs are nontrivial in the model's balanced growth path. We assume that labor in each sector has grown proportionately between 1987 and 1988. Not imposing some sort of adjustment cost in 1988 results in a sharp drop in output in 1989. The adjustment costs in 1988 require us to recalibrate all of the parameters of each production function so that the equilibrium replicates the 1988 input-output matrix. 
The labor adjustment cost function adds a new parameter, $\theta$, that we calibrate to match the reallocation of labor across the two sectors that we find in the data. In Mexico, as in most industrialized countries, the share of labor used in the traded sector has a negative trend. During the sudden stop, labor stops moving out of the traded sector and even increases by a small amount; this amounts to - relative to the trend - a significant reallocation of workers to the traded sector. We could model this by specifying different rates of growth of technological progress, $g_{D}>g_{N}$, in the production functions. Instead, we abstract from the secular trend in employment, so we remove a least-squares linear time trend both from the data and from the model. Figure 11(a) plots the detrended ratio of traded labor to total labor. We set $\theta=6.468$ so that the reallocation from 1994 to 1997 is the same in the model as in the data.

The results for the model with labor frictions are summarized in table 4. Labor frictions have their largest impact on the price of nontraded goods, as shown in figure 11(b). The frictions restrict the amount of traded goods that can be produced, leading to higher traded good prices in this model relative to the baseline model. The bilateral price of nontraded goods in Mexico falls 31.38 percent, more than five times that in the baseline model. The large movement in the relative price of nontraded goods causes the real exchange rate to depreciate during the sudden stop by 61.30 percent compared to 41.36 in the baseline model.

Returning to the original argument for including these costs, we can see from table 4 that GDP rises by about half as much as in the baseline model and TFP falls by 0.26 percent; the movements are nowhere near as large as those in the data. It is worth noting that movements in TFP are not monotonic in the cost parameter $\theta$ : setting $\theta$ very high results in very little movement of labor and very low costs incurred.

\subsection{Variable capital utilization}

Our third candidate explanation is variable capital utilization. Firms choose how much to utilize the capital stock, but the more that capital is used, the higher is the depreciation rate. The trade-off implies that when the marginal product of capital is low, the agents will choose not to use it as much. In the eyes of the statistician, though, capital is 
measured the same way regardless of utilization, which is unobserved. This measurement issue implies that a decrease in utilization will appear as low productivity. The law of motion for capital in the domestic traded sector is

$$
k_{D t+1}=\left(1-\delta\left(u_{D t}\right)\right) k_{D t}+i_{D t},
$$

where

$$
\delta\left(u_{D t}\right)=\bar{\delta}+\frac{\chi}{\omega}\left(u_{D t}^{\omega}-1\right)
$$

Value added in the production function (5) is now $A_{D}\left(u_{D t} k_{D t}\right)^{\alpha_{D}}\left(g^{t} \ell_{D t}\right)^{1-\alpha_{D}}$. We assume that the traded sector has the same utilization technology. Here capital utilization is $u$; the parameter $\omega$ governs the curvature of the depreciation function; and $\bar{\delta}$ and $\chi$ are parameters calibrated so that depreciation in 1988 is equal to that in the data and so that $u_{D 1988}=u_{N 1988}=1$. This specification nests our baseline specification in the limiting case where $\omega$ tends to infinity and the specification of Greenwood, Hercowitz, and Huffman (1988) in the case where $\chi / \omega=\bar{\delta}$.

We first consider the case where we calibrate $\omega=3.751$ so that $\chi / \omega=\bar{\delta}$. The results are summarized in table 4 . The model can generate about one-third of the drop in the TFP factor, but GDP still increases during the sudden stop. This is because utilization is another margin on which to adjust. During the sudden stop, traded capital utilization increases and nontraded capital utilization decreases, as in figure 12(b). This allows the economy to produce more traded output than it could in the baseline model.

If we combine the labor frictions and variable capital utilization, we can account for the observed fall in TFP. We set $\omega=6.510$ and $\theta=8.964$, producing both the drop in TFP and the reallocation of labor observed in the data. In this specification, $\chi / \omega<\bar{\delta}$. The labor friction makes it more difficult to move labor across the sectors, so the change in capital utilization is larger, creating the larger drop in TFP. The model with both frictions also decreases GDP almost as much as in the data. Notice, however, that the other results generated by the model are sharply at odds with the data: the trade balance, real exchange rate, and relative price of nontraded goods fluctuate wildly. By limiting 
the movements in labor, the model forces adjustments to take place elsewhere. While combining frictions can match the observed drop in TFP, it destroys the model's ability to account for other parts of the data.

\subsection{Quasilinear utility}

When the baseline model is hit with a sudden stop, the labor input increases because the wealth effect of the sudden stop overwhelms the substitution effect. Households prefer to work more during the sudden stop and to consume less leisure to make up for the loss of income. In some small open economy models, however, the period utility function is specified as a quasilinear function, as in Greenwood, Hercowitz, and Huffman (1988),

$$
u\left(c_{T t}, c_{N t}, \ell_{t}\right)=\frac{1}{\psi}\left(\left(\left(\varepsilon\left(\frac{c_{T t}}{n_{t}}\right)^{\rho}+(1-\varepsilon)\left(\frac{c_{N t}}{n_{t}}\right)^{\rho}\right)^{\frac{1}{\rho}}-\lambda g^{t}\left(\frac{\ell_{t}}{\bar{\ell}_{t}}\right)^{\eta}\right)^{\psi}-1\right)
$$

so that there is no wealth effect on labor supply. As Chakraborty (2006) points out, using this utility function in a one sector model of sudden stops eliminates the increase in labor because of the wealth effect generated by a standard utility function.

We consider a model with a utility in which $\psi=0$, that is, in which intertemporal utility is logarithmic, because we cannot calibrate a value of $\beta$ less than 1 if $\psi=-1$. We set $\eta=3$ and calibrate $\lambda$ to match hours worked in 1988. Table 5 reports the results. These results are very similar to the baseline model, except the increase in labor during the sudden stop is less than half of that in the baseline model. Labor still increases because of the increase in working age population. Labor per working age person declines slightly because of a small drop in the wage relative to the prices of consumption goods. One problem with the quasilinear utility function is that it produces a large positive trend in labor as the economy increases its capital-output ratio.

\subsection{Exogenous decrease in TFP}

Our simple model, in which a sudden stop acts on an economy through the interaction of traded and nontraded goods, is successful in reproducing many features of the Mexican crisis, but is unable to account for the change in GDP. In this section, we consider a 
version of the model with an exogenous TFP shock. This exercise is not to suggest we should be content to model the observed decrease in TFP as exogenous, but rather to show that our model is capable of delivering decreases in aggregate output while still accounting for the trade flows and prices.

We modify the baseline model by allowing for a one-time, exogenous TFP drop. We introduce variation in TFP at the aggregate level by allowing the technological growth rate parameter in the domestic traded production function to vary with time,

$$
y_{D t}=\min \left[z_{T D t} / a_{T D}, z_{N D t} / a_{N D}, A_{D} k_{D t}^{\alpha_{D}}\left(\left(v_{t} g\right)^{t} \ell_{D t}\right)^{1-\alpha_{D}}\right],
$$

and similarly for the nontraded production function. The shock to total factor productivity, $v_{t}$, is the same across industries. We assume that $v_{t}$ is equal to 1 for all years before 1995, and is equal to $v<1$ for 1995 and thereafter. This implies that TFP in the model falls exactly as much as it does in the data, as can be seen in figure 13(b).

We assume that agents are surprised by the TFP shock in the same way they are surprised about the sudden stop; they do not foresee the TFP drop, but they perfectly foresee the path of TFP afterward. We compute the model using both the standard utility function, where we calibrate $v=0.880$, and the quasilinear utility function, where we calibrate $v=0.878$. The results of the models are summarized in table 5. In both models, the TFP drop has little effect on the results on prices and the trade balance. Where the TFP shock does matter is in the labor supply decision. The drop in productivity makes wages fall during the sudden stop. In the model with standard preferences, this causes labor to rise less than in the baseline model, but the wealth effect is still strong enough to increase labor. With quasilinear utility, the substitution effect causes labor input to fall, even more so than in the data. Overall, the exogenous drop in TFP makes the model fit the data - particularly the data on output — better.

To capture the drop in labor during the sudden stop, there are alternatives to quasilinear utility. Meza (2007), for example, shows that increases in taxes on labor and consumption in 1995 can account for the decrease in labor in a model with a standard utility function. Including taxes in our model, as in Conesa, Kehoe, and Ruhl (2007), could also help us account for the sharp drop in consumption that occurred in Mexico in 
1995. As Meza (2007) points out, the value added tax in Mexico increased sharply that year. Tornell and Westermann (2002) point out that the severity of this drop was unusual among sudden stop experiences, and our model has trouble accounting for it.

That large exogenous changes in TFP can account for large changes in output in models like this is not a new result. For example, many of the papers in Kehoe and Prescott (2007) have shown that the large declines in output that make up great depressions can be accounted for by exogenous drops in TFP. We do not, however, believe that, for an exogenous reason unrelated to the sudden stop, TFP fell in 1995, but we leave identifying the inefficiencies set into motion by the sudden stop to future work, such as Mendoza (2006). In this section, we have shown that, when the model is modified to produce a large decline in aggregate output, our results concerning prices and trade flows are largely unchanged.

\section{Conclusion}

We have studied sudden stops focusing on their effects on the traded sector relative to the nontraded sector. In the data, we find that the nontraded sector suffers a larger decline in output and a slower recovery from the sudden stop. Resources are transferred from the nontraded sector to the traded sector and the relative price of traded goods increases. These facts provide insights into how sudden stops may move through the economy namely, through relative price effects.

We have constructed a simple model with traded and nontraded goods and calibrated it to Mexico. When we subject the model to a sudden stop - and nothing else

- the model can account for the depreciation in real exchange rates and the trade balance reversal. Though the simple model can account for prices and the behavior of the disaggregated economy, it cannot account for the changes in aggregate TFP and GDP.

Introducing frictions in terms of labor adjustment costs and variable capital utilization into the model can produce a decline in TFP. If these frictions are large enough to account for the observed decrease in TFP, however, they generate wild results for the other variables. The results for a model with an exogenous decrease in TFP indicate that identifying another mechanism by which the sudden stop causes a drop in TFP — possibly in combination with the frictions that we have studied — is needed. 


\section{References}

Bems, R. (2008), “Aggregate Investment Expenditures on Tradable and Nontradable Goods," Review of Economics Dynamics, 11(4), 852-83.

Bems, R. and K. Jönsson Hartelius (2006), “Trade Deficits in the Baltic States: How Long Will the Party Last?” Review of Economic Dynamics, 9(1), 179-209.

Bergoeing R., P. J. Kehoe, T. J. Kehoe, and R. Soto (2002), “A Decade Lost and Found: Mexico and Chile in the 1980s," Review of Economic Dynamics, 5(1), 166-205.

Betts, C. M. and T. J. Kehoe (2001), "Tradability of Goods and Real Exchange Rate Fluctuations," University of Minnesota.

Burstein, A., M. Eichenbaum, and S. Rebelo (2005), "Large Devaluations and the Real Exchange Rate," Journal of Political Economy, 113(4), 742-84.

Calvo, G. A. (1988), "Servicing the Public Debt: The Role of Expectations," American Economic Review, 78(4), 647-61.

Calvo, G. A. (1998), "Capital Flows and Capital-Market Crises: The Simple Economics of Sudden Stops,” Journal of Applied Economics, 1(1), 35-54.

Calvo, G. A. and E. Talvi (2005), "Sudden Stop, Financial Factors and Economic Collapse in Latin America: Learning from Argentina and Chile," NBER Working Paper 11153.

Chakraborty, S. (2006), "Modeling Sudden Stops: The Role of Preferences,” Baruch College, City University of New York.

Chari, V. V., P. J. Kehoe, and E. R. McGrattan (2005), "Sudden Stops and Output Drops," American Economic Review, 95(2), 381-87.

Cole, H. L. and L. E. Ohanian (1999), "The Great Depression in the United States from a Neoclassical Perspective," Federal Reserve Bank of Minneapolis Quarterly Review, 23(1), 2-24.

Cole, H. L. and T. J. Kehoe (2000), "Self-Fulfilling Debt Crises," Review of Economic Studies, 67(1), 91-116.

Conesa, J. C., T. J. Kehoe, and K. J. Ruhl (2007), "Modeling Great Depressions: The Depression in Finland in the 1990s," Federal Reserve Bank of Minneapolis Quarterly Review, 31(1), 16-44.

Cook, D. E. and M. B. Devereux (2006), "External Currency Pricing and the East Asian Crisis," Journal of International Economics, 69(1), 37-63. 
Fernández de Córdoba, G. and T. J. Kehoe (2000), "Capital Flows and Real Exchange Rate Fluctuations Following Spain's Entry into the European Community," Journal of International Economics, 51(1), 49-78.

García-Verdú, R. (2005), “Factor Shares from Household Survey Data,” Banco de México Working Paper 2005-05.

Greenwood, J., Z. Hercowitz, and G.W. Huffman (1988), "Investment, Capacity Utilization, and the Real Business Cycle," American Economic Review, 78(3), 402-17.

Guidotti, P. E., F. Sturzenegger, and A. Villar (2004), "On the Consequences of Sudden Stops," Economia: Journal of the Latin American and Caribbean Economic Association, 4(2), 171-203.

Hayashi, F. and E. C. Prescott (2002), "The 1990s in Japan: A Lost Decade," Review of Economic Dynamics, 5(1), 206-35.

Kaminsky, G. L. and C. M. Reinhart (1999), "The Twin Crises: The Causes of Banking and Balance-of-Payments Problems," American Economic Review, 89(3), 473-500.

Kehoe, P. J. and T. J. Kehoe (1994), "A Primer on Static Applied General Equilibrium Models," Federal Reserve Bank of Minneapolis Quarterly Review, 18(2), 2-16.

Kehoe, T. J. (1995a) “A Review of Mexico's Trade Policy from 1982 to 1994," World Economy, 18(4), 135-51.

Kehoe, T. J. (1995b), "What Happened in Mexico in 1994-95?" in P. J. Kehoe and T. J. Kehoe, editors, Modeling North American Economic Integration, Kluwer Academic Publishers, 131-47.

Kehoe, T. J. and E. C. Prescott (2002), "Great Depressions of the Twentieth Century," Review of Economic Dynamics, 5(1), 1-18.

Kehoe, T. J. and E. C. Prescott, editors (2007), Great Depressions of the Twentieth Century. Federal Reserve Bank of Minneapolis.

Kehoe, T. J. and K. J. Ruhl (2008), "Are Shocks to the Terms of Trade Shocks to Productivity?" Review of Economic Dynamics, 11(4), 804-19.

Kravis, I. B., A. W. Heston, and R. Summers (1982), World Product and Income: International Comparisons of Real Gross Product. Published for the World Bank by the Johns Hopkins University Press.

McGrattan, E. R. and E. C. Prescott (2003), “Average Debt and Equity Returns: Puzzling?” American Economic Review, 93(2), 392-97. 
Mendoza, E. G. (2000), “On the Instability of Variance Decompositions of the Real Exchange Rate across Exchange Rate Regimes: Evidence from Mexico and the United States," NBER Working Paper 7768.

Mendoza, E. G. (2005), "Real Exchange Rate Volatility and the Price of Nontradables in Sudden-Stop-Prone Economies,” NBER Working Paper 11691.

Mendoza, E. G. (2006), "Endogenous Sudden Stops in a Business Cycle Model with Collateral Constraints: A Fisherian Deflation of Tobin's Q," NBER Working Paper 12564.

Mendoza, E. G. and K. A. Smith (2004), "Quantitative Implication of A Debt-Deflation Theory of Sudden Stops and Asset Prices," NBER Working Paper 10940.

Meza, F. (2007), "Financial Crises, Fiscal Policy, and the 1995 GDP Contraction in Mexico," Universidad Carlos III de Madrid.

Meza, F. and E. Quintin (2007), "Factor Utilization and the Real Impact of Financial Crises," B. E. Journal of Macroeconomics (Advances), 7(1), article 33.

Neumeyer, P. A. and F. Perri (2005), "Business Cycles in Emerging Economies: The Role of Interest Rates,” Journal of Monetary Economics, 52(2), 345-80.

Ruhl, K. J. (2008), “The International Elasticity Puzzle,” University of Texas at Austin.

Sargent, T. J. (1978), "Estimation of Dynamic Labor Demand Schedules under Rational Expectations," Journal of Political Economy, 86(6), 1009-44.

Schneider, M. and A. Tornell (2004), "Balance Sheet Effects, Bailout Guarantees and Financial Crises," Review of Economic Studies, 71(3), 883-913.

Stockman, A. C. and L. L. Tesar (1995), "Tastes and Technology in a Two-Country Model of the Business Cycle: Explaining International Comovements," American Economic Review, 85(1), 168-85.

Tornell, A. and F. Westermann (2002), "Boom-Bust Cycles in Middle Income Countries: Facts and Explanation," NBER Working Paper 9219. 
Table 1

1988 Input-Output Matrix

\begin{tabular}{|c|c|c|c|c|c|c|c|c|}
\hline \multirow[b]{2}{*}{ Commodity } & \multicolumn{3}{|c|}{ Inputs } & \multicolumn{4}{|c|}{ Final demand } & \multirow[b]{2}{*}{ 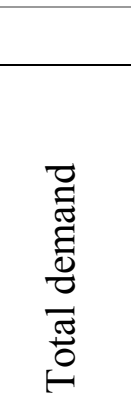 } \\
\hline & 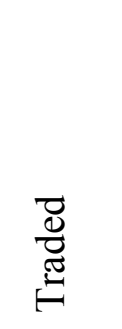 & 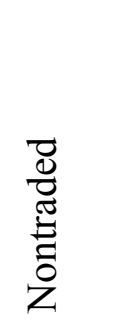 & 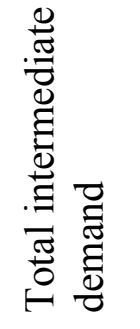 & 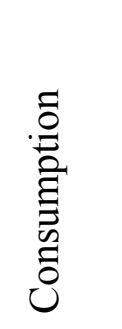 & 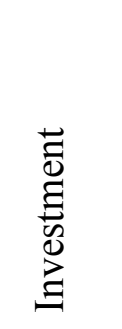 & 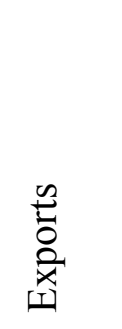 & 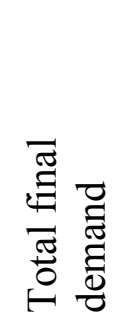 & \\
\hline Traded & 33.54 & 9.28 & 42.82 & 27.05 & 10.16 & 19.93 & 57.14 & 99.96 \\
\hline Nontraded & 13.13 & 20.53 & 33.66 & 49.00 & 12.40 & 0.00 & 61.40 & 95.06 \\
\hline Total intermediate consumption & 46.67 & 29.81 & 76.48 & 76.05 & 22.56 & 19.93 & 118.54 & 195.02 \\
\hline Labor compensation & 22.11 & 38.74 & 60.85 & & & & & 60.85 \\
\hline Return to capital & 10.79 & 26.51 & 37.30 & & & & & 37.30 \\
\hline Value added & 32.89 & 65.26 & 98.15 & & & & & 98.15 \\
\hline Imports & 18.54 & 0.00 & 18.54 & & & & & 18.54 \\
\hline Tariffs & 1.85 & 0.00 & 1.85 & & & & & 1.85 \\
\hline Total gross output & 99.96 & 95.06 & 195.02 & 76.05 & 22.56 & 19.93 & 118.54 & 313.56 \\
\hline
\end{tabular}


Table 2

Calibration of model

\begin{tabular}{|c|c|c|c|}
\hline Parameter & Value & Statistic & Target \\
\hline \multicolumn{4}{|c|}{ Consumer parameters } \\
\hline$b_{1988}$ & -8.831 & Trade balance to GDP in 1988 , in percent & 1.390 \\
\hline$k_{1988}$ & 169.817 & Real interest rate in 1988 , in percent & 15.740 \\
\hline$\beta$ & 0.987 & U.S. real interest rate, in percent & 4.000 \\
\hline$\varepsilon$ & 0.234 & Traded good share in consumption in 1988 & 0.356 \\
\hline$\rho$ & -1.000 & Elasticity of substitution: traded to nontraded & 0.500 \\
\hline$\eta$ & 0.306 & Ratio of hours worked to available hours in 1988 & 0.267 \\
\hline$\psi$ & -1.000 & Intertemporal elasticity of substitution & 0.500 \\
\hline$\delta$ & 0.062 & Depreciation to GDP in 1988 , in percent & 10.566 \\
\hline$\tau_{K 1989}$ & 0.201 & Investment in 1988 & 22.561 \\
\hline \multicolumn{4}{|c|}{ Producer parameters } \\
\hline$a_{T D}$ & 0.422 & Share of traded inputs in domestic traded in 1988 & 0.422 \\
\hline$a_{N D}$ & 0.165 & Share of nontraded inputs in domestic traded in 1988 & 0.165 \\
\hline$a_{T N}$ & 0.098 & Share of traded inputs in domestic nontraded in 1988 & 0.098 \\
\hline$a_{N N}$ & 0.216 & Share of nontraded inputs in domestic nontraded in 1988 & 0.216 \\
\hline$A_{D}$ & 2.770 & Traded gross output in 1988 & 79.564 \\
\hline$A_{N}$ & 1.546 & Nontraded gross output in 1988 & 95.065 \\
\hline$\alpha_{D}$ & 0.328 & Capital's share of domestic traded value added in 1988 & 0.328 \\
\hline$\alpha_{N}$ & 0.406 & Capital's share of nontraded value added in 1988 & 0.406 \\
\hline$\gamma$ & 0.450 & Share of traded inputs in investment good production in 1988 & 0.450 \\
\hline$G$ & 1.990 & Investment in 1988 & 22.561 \\
\hline$g$ & 1.020 & Growth rate of U.S. GDP per working age person, in percent & 2.000 \\
\hline \multicolumn{4}{|c|}{ Trade parameters } \\
\hline M & 1.866 & Total traded goods in 1988 & 99.955 \\
\hline$\mu$ & 0.653 & Ratio of imports to domestic traded good in 1988 & 0.233 \\
\hline$\zeta$ & 0.500 & Elasticity of substitution: domestic traded to imports & 2.000 \\
\hline$D_{1988}$ & 21.141 & Exports in 1988 & 19.928 \\
\hline \multicolumn{4}{|c|}{ Time series of parameters } \\
\hline $\bar{\ell}_{t}$ & & Mexican working age population data and projections & \\
\hline$n_{t}$ & & Mexican adult equivalent population data and projections & \\
\hline$\sigma_{t}$ & & Mexican interest premia & \\
\hline$D_{t}$ & & U.S. working age population data and projections & \\
\hline$\tau_{t}$ & & Mexican tariffs on U.S. imposts & \\
\hline$\tau_{F t}$ & & U.S. tariffs on Mexican imports & \\
\hline
\end{tabular}


Table 3

Numerical experiments: Sensitivity analysis

\begin{tabular}{|c|c|c|c|c|c|c|c|}
\hline & & Data & Baseline & $\begin{array}{l}\text { No interest } \\
\text { rate premia }\end{array}$ & $\begin{array}{l}\text { No population } \\
\text { growth }\end{array}$ & No tariffs & Terms of trade \\
\hline \multirow{3}{*}{$\begin{array}{c}\mathrm{TB} / \mathrm{Y}^{*} 100 \\
\text { (difference) }\end{array}$} & 1988-1994| & -1.04 & -1.36 & -2.20 & -0.21 & -1.41 & -1.36 \\
\hline & 1994-1995 & 7.49 & 11.80 & 17.29 & 0.14 & 13.21 & 10.68 \\
\hline & $1995-2000$ & -0.93 & -0.80 & -2.79 & 1.46 & -1.05 & -0.65 \\
\hline \multirow{3}{*}{$\begin{array}{c}\text { RER } \\
\text { (percent change) }\end{array}$} & 1988-1994 & -6.25 & -2.06 & -4.97 & 1.15 & -2.79 & -2.06 \\
\hline & 1994-1995 & 31.49 & 36.93 & 54.93 & 3.69 & 42.00 & 14.17 \\
\hline & $1995-2000$ & -5.81 & -3.05 & -8.28 & 1.88 & -3.99 & -2.47 \\
\hline \multirow{3}{*}{$\begin{array}{c}\text { RERN } \\
\text { (percent change) }\end{array}$} & 1988-1994 & -2.64 & -1.05 & -1.16 & -0.82 & -1.03 & -1.05 \\
\hline & 1994-1995 & 6.19 & 5.52 & 7.63 & 0.60 & 5.93 & 3.73 \\
\hline & $1995-2000$ & -0.99 & -2.32 & -2.76 & -1.42 & -2.41 & -2.17 \\
\hline \multirow{3}{*}{$\begin{array}{c}\text { Tot } \\
\text { (percent change) }\end{array}$} & 1988-1994 & -1.77 & -0.63 & -2.76 & 1.73 & -1.42 & -0.63 \\
\hline & 1994-1995 & 8.31 & 25.31 & 37.39 & 2.59 & 29.74 & 8.31 \\
\hline & $1995-2000$ & -1.70 & -0.51 & -4.34 & 2.80 & -1.33 & -0.14 \\
\hline \multirow{3}{*}{$\begin{array}{c}\mathrm{C} / \mathrm{N} \\
\text { (percent change) }\end{array}$} & 1988-1994 & 2.54 & 3.97 & 4.98 & 1.30 & 3.92 & 3.97 \\
\hline & 1994-1995 & -15.86 & -1.08 & 5.76 & -2.79 & -0.21 & -0.78 \\
\hline & $1995-2000$ & 3.34 & 3.52 & 2.83 & 2.23 & 3.35 & 3.81 \\
\hline \multirow{3}{*}{$\begin{array}{c}\mathrm{I} / \mathrm{N} \\
\text { (percent change) }\end{array}$} & 1988-1994 & 0.42 & 14.82 & 16.82 & 12.57 & 14.95 & 14.82 \\
\hline & 1994-1995 & -18.03 & -10.64 & -65.36 & 18.09 & -14.64 & -5.71 \\
\hline & $1995-2000$ & 6.81 & 2.86 & 15.01 & -7.32 & 3.68 & 2.44 \\
\hline \multirow{3}{*}{$\begin{array}{c}\mathrm{X} / \mathrm{N} \\
\text { (percent change) }\end{array}$} & 1988-1994 & -1.76 & -1.28 & -7.61 & 4.59 & -3.89 & -1.28 \\
\hline & 1994-1995 & 50.32 & 65.90 & 97.71 & 6.24 & 75.82 & 73.70 \\
\hline & $1995-2000$ & 3.52 & -0.89 & -10.40 & 6.55 & -3.10 & 0.15 \\
\hline \multirow{3}{*}{$\begin{array}{c}\mathrm{M} / \mathrm{N} \\
\text { (percent change) }\end{array}$} & 1988-1994 & 3.64 & 7.06 & 8.56 & 4.93 & 5.92 & 7.06 \\
\hline & 1994-1995 & 15.94 & 0.62 & -10.04 & 5.50 & -3.04 & 15.57 \\
\hline & $1995-2000$ & 6.61 & 2.82 & 5.33 & 0.08 & 2.10 & 2.90 \\
\hline \multirow{3}{*}{$\begin{array}{c}\text { GDP/N } \\
\text { (percent change) }\end{array}$} & 1988-1994 & 1.06 & 5.82 & 6.43 & 4.41 & 5.79 & 5.82 \\
\hline & 1994-1995 & -8.89 & 7.26 & 1.30 & 5.56 & 7.92 & 8.00 \\
\hline & $1995-2000$ & 3.16 & 2.48 & 3.59 & 0.30 & 2.37 & 2.67 \\
\hline \multirow{3}{*}{$\begin{array}{c}\text { TFP factor } \\
\text { (percent change) }\end{array}$} & 1988-1994 & 0.20 & 2.14 & 2.65 & 1.80 & 2.13 & 2.14 \\
\hline & 1994-1995 & -12.69 & 0.00 & -1.24 & 1.75 & 1.42 & 1.11 \\
\hline & $1995-2000$ & 2.77 & 1.81 & 2.26 & 1.64 & 1.77 & 1.95 \\
\hline \multirow{3}{*}{$\begin{array}{c}\text { Capital factor } \\
\text { (percent change) }\end{array}$} & 1988-1994 & 0.20 & 2.39 & 3.16 & 3.16 & 2.46 & 2.39 \\
\hline & 1994-1995 & 6.18 & 0.77 & 5.22 & 0.63 & 0.22 & 0.32 \\
\hline & $1995-2000$ & -0.94 & 1.56 & 1.20 & 2.18 & 1.52 & 1.65 \\
\hline \multirow{3}{*}{$\begin{array}{c}\text { Labor factor } \\
\text { (percent change) }\end{array}$} & 1988-1994 & 0.65 & 1.29 & 0.97 & -0.54 & 1.20 & 1.29 \\
\hline & 1994-1995 & -2.38 & 6.49 & -2.30 & 3.18 & 6.29 & 6.57 \\
\hline & $1995-2000$ & 1.33 & -0.89 & 0.30 & -3.53 & -0.92 & -0.93 \\
\hline
\end{tabular}


Table 4

Numerical experiments: Adjustment frictions

\begin{tabular}{|c|c|c|c|c|c|c|}
\hline & & Data & Baseline & $\begin{array}{c}\text { Labor } \\
\text { frictions }\end{array}$ & $\begin{array}{c}\text { Variable } \\
\text { capital } \\
\text { utilization }\end{array}$ & $\begin{array}{c}\text { Labor } \\
\text { frictions and } \\
\text { VCU }\end{array}$ \\
\hline \multirow{3}{*}{$\begin{array}{c}\mathrm{TB} / \mathrm{Y}^{*} 100 \\
\text { (difference) }\end{array}$} & 1988-1994 & -1.04 & -1.36 & -1.63 & -2.13 & -2.50 \\
\hline & 1994-1995 & 7.49 & 11.80 & 17.40 & 21.04 & 37.50 \\
\hline & $1995-2000$ & -0.93 & -0.80 & -1.93 & -2.64 & -5.92 \\
\hline \multirow{3}{*}{$\begin{array}{c}\text { RER } \\
\text { (percent change) }\end{array}$} & 1988-1994 & -6.25 & -2.06 & -2.91 & -2.90 & -4.99 \\
\hline & 1994-1995 & 31.49 & 36.93 & 65.59 & 61.73 & 110.77 \\
\hline & $1995-2000$ & -5.81 & -3.05 & -8.06 & -6.38 & -14.80 \\
\hline \multirow{3}{*}{$\begin{array}{c}\text { RERN } \\
\text { (percent change) }\end{array}$} & 1988-1994 & -2.64 & -1.05 & -1.29 & -1.05 & -1.38 \\
\hline & 1994-1995 & 6.19 & 5.52 & 31.30 & 6.80 & 44.69 \\
\hline & $1995-2000$ & -0.99 & -2.32 & -7.19 & -2.38 & -9.49 \\
\hline \multirow{3}{*}{$\begin{array}{c}\text { Tot } \\
\text { (percent change) }\end{array}$} & 1988-1994 & -1.77 & -0.63 & -1.11 & -1.28 & -2.61 \\
\hline & 1994-1995 & 8.31 & 25.31 & 27.51 & 44.74 & 53.26 \\
\hline & $1995-2000$ & -1.70 & -0.51 & -0.63 & -3.27 & -4.34 \\
\hline \multirow{3}{*}{$\begin{array}{c}\mathrm{C} / \mathrm{N} \\
\text { (percent change) }\end{array}$} & 1988-1994 & 2.54 & 3.97 & 3.44 & 2.77 & 2.64 \\
\hline & 1994-1995 & -15.86 & -1.08 & -2.93 & 2.45 & -5.43 \\
\hline & $1995-2000$ & 3.34 & 3.52 & 4.36 & 4.21 & 6.67 \\
\hline \multirow{3}{*}{$\begin{array}{c}\mathrm{I} / \mathrm{N} \\
\text { (percent change) }\end{array}$} & 1988-1994 & 0.42 & 14.82 & 17.70 & 27.67 & 27.09 \\
\hline & 1994-1995 & -18.03 & -10.64 & -33.72 & -34.81 & -84.49 \\
\hline & $1995-2000$ & 6.81 & 2.86 & 8.37 & 10.01 & 21.29 \\
\hline \multirow{3}{*}{$\begin{array}{c}\mathrm{X} / \mathrm{N} \\
\text { (percent change) }\end{array}$} & 1988-1994 & -1.76 & -1.28 & -2.96 & -3.14 & -7.45 \\
\hline & 1994-1995 & 50.32 & 65.90 & 102.29 & 112.24 & 179.99 \\
\hline & $1995-2000$ & 3.52 & -0.89 & -7.05 & -7.27 & -18.65 \\
\hline \multirow{3}{*}{$\begin{array}{c}\mathrm{M} / \mathrm{N} \\
\text { (percent change) }\end{array}$} & 1988-1994 & 3.64 & 7.06 & 7.73 & 12.10 & 12.01 \\
\hline & 1994-1995 & 15.94 & 0.62 & 14.88 & -13.39 & 7.57 \\
\hline & $1995-2000$ & 6.61 & 2.82 & 0.31 & 5.88 & 2.56 \\
\hline \multirow{3}{*}{$\begin{array}{c}\text { GDP/N } \\
\text { (percent change) }\end{array}$} & 1988-1994 & 1.06 & 5.82 & 6.36 & 10.45 & 9.74 \\
\hline & 1994-1995 & -8.89 & 7.26 & 2.98 & 3.89 & -2.19 \\
\hline & $1995-2000$ & 3.16 & 2.48 & 3.81 & 4.46 & 6.80 \\
\hline \multirow{3}{*}{$\begin{array}{c}\text { TFP factor } \\
\text { (percent change) }\end{array}$} & 1988-1994 & 0.20 & 2.14 & 3.00 & 1.36 & 4.39 \\
\hline & 1994-1995 & -12.69 & 0.00 & -1.98 & -4.75 & -12.69 \\
\hline & $1995-2000$ & 2.77 & 1.81 & 2.29 & 2.49 & 5.28 \\
\hline \multirow{3}{*}{$\begin{array}{c}\text { Capital factor } \\
\text { (percent change) }\end{array}$} & 1988-1994 & 0.20 & 2.39 & 2.80 & 3.88 & 3.73 \\
\hline & 1994-1995 & 6.18 & 0.77 & 4.42 & 6.81 & 10.84 \\
\hline & $1995-2000$ & -0.94 & 1.56 & 1.06 & 2.03 & 0.39 \\
\hline \multirow{3}{*}{$\begin{array}{c}\text { Labor factor } \\
\text { (percent change) }\end{array}$} & 1988-1994 & 0.65 & 1.29 & 0.55 & 5.20 & 1.62 \\
\hline & 1994-1995 & -2.38 & 6.49 & 0.54 & 1.84 & -0.35 \\
\hline & $1995-2000$ & 1.33 & -0.89 & 0.47 & -0.07 & 1.14 \\
\hline
\end{tabular}




\section{Table 5}

Numerical experiments: Quasilinear utility and exogenous TFP

\begin{tabular}{|c|c|c|c|c|c|c|}
\hline & & Data & Baseline & $\begin{array}{c}\text { Quasilinear } \\
\text { utility }\end{array}$ & $\begin{array}{l}\text { Exogenous } \\
\text { TFP }\end{array}$ & $\begin{array}{l}\text { Exogenous TFP and } \\
\text { quasilinear utility }\end{array}$ \\
\hline $\mathrm{TB} / \mathrm{Y}^{*} 100$ & 1988-1994 & -1.04 & -1.36 & -1.36 & -1.36 & -1.36 \\
\hline \multirow[t]{2}{*}{ (difference) } & 1994-1995 & 7.49 & 11.80 & 11.55 & 12.09 & 11.88 \\
\hline & $1995-2000$ & -0.93 & -0.80 & -0.76 & -0.70 & -0.59 \\
\hline RER & 1988-1994 & -6.25 & -2.06 & -2.00 & -2.06 & -2.00 \\
\hline \multirow[t]{2}{*}{ (percent change) } & 1994-1995 & 31.49 & 36.93 & 34.90 & 34.36 & 31.79 \\
\hline & $1995-2000$ & -5.81 & -3.05 & -2.67 & -3.01 & -2.62 \\
\hline RERN & 1988-1994 & -2.64 & -1.05 & -1.05 & -1.05 & -1.05 \\
\hline \multirow[t]{2}{*}{ (percent change) } & 1994-1995 & 6.19 & 5.52 & 5.63 & 5.84 & 5.99 \\
\hline & $1995-2000$ & -0.99 & -2.32 & -2.34 & -2.38 & -2.40 \\
\hline Tot & 1988-1994 & -1.77 & -0.63 & -0.58 & -0.63 & -0.58 \\
\hline \multirow[t]{2}{*}{ (percent change) } & 1994-1995 & 8.31 & 25.31 & 23.58 & 22.94 & 20.72 \\
\hline & $1995-2000$ & -1.70 & -0.51 & -0.18 & -0.43 & -0.09 \\
\hline $\mathrm{C} / \mathrm{N}$ & 1988-1994 & 2.54 & 3.97 & 3.73 & 3.97 & 3.73 \\
\hline \multirow[t]{2}{*}{ (percent change) } & 1994-1995 & -15.86 & -1.08 & -2.44 & -8.30 & -11.04 \\
\hline & $1995-2000$ & 3.34 & 3.52 & 4.00 & 2.97 & 3.09 \\
\hline $\mathbf{I} / \mathbf{N}$ & 1988-1994 & 0.42 & 14.82 & 15.46 & 14.82 & 15.46 \\
\hline \multirow[t]{2}{*}{ (percent change) } & 1994-1995 & -18.03 & -10.64 & -17.71 & -22.17 & -31.66 \\
\hline & $1995-2000$ & 6.81 & 2.86 & 4.05 & 2.32 & 2.97 \\
\hline $\mathbf{X} / \mathbf{N}$ & 1988-1994 & -1.76 & -1.28 & -1.14 & -1.28 & -1.14 \\
\hline \multirow[t]{2}{*}{ (percent change) } & 1994-1995 & 50.32 & 65.90 & 62.00 & 60.80 & 55.83 \\
\hline & $1995-2000$ & 3.52 & -0.89 & -0.16 & -0.76 & 0.01 \\
\hline $\mathbf{M} / \mathbf{N}$ & 1988-1994 & 3.64 & 7.06 & 7.15 & 7.06 & 7.15 \\
\hline \multirow[t]{2}{*}{ (percent change) } & 1994-1995 & 15.94 & 0.62 & -1.90 & -5.13 & -8.82 \\
\hline & $1995-2000$ & 6.61 & 2.82 & 3.33 & 2.37 & 2.58 \\
\hline GDP/N & 1988-1994 & 1.06 & 5.82 & 5.91 & 5.82 & 5.91 \\
\hline \multirow[t]{2}{*}{ (percent change) } & 1994-1995 & -8.89 & 7.26 & 3.56 & -1.10 & -6.48 \\
\hline & $1995-2000$ & 3.16 & 2.48 & 3.24 & 2.03 & 2.44 \\
\hline \multirow{3}{*}{$\begin{array}{c}\text { TFP factor } \\
\text { (percent change) }\end{array}$} & 1988-1994 & 0.20 & 2.14 & 2.14 & 2.14 & 2.14 \\
\hline & 1994-1995 & -12.69 & 0.00 & 0.32 & -12.69 & -12.69 \\
\hline & $1995-2000$ & 2.77 & 1.81 & 1.78 & 1.85 & 1.83 \\
\hline \multirow{3}{*}{$\begin{array}{l}\text { Capital factor } \\
\text { (percent change) }\end{array}$} & 1988-1994 & 0.20 & 2.39 & 2.27 & 2.39 & 2.27 \\
\hline & 1994-1995 & 6.18 & 0.77 & 3.49 & 5.89 & 9.64 \\
\hline & $1995-2000$ & -0.94 & 1.56 & 1.03 & 1.00 & 0.44 \\
\hline \multirow{3}{*}{$\begin{array}{c}\text { Labor factor } \\
\text { (percent change) }\end{array}$} & 1988-1994 & 0.65 & 1.29 & 1.50 & 1.29 & 1.50 \\
\hline & 1994-1995 & -2.38 & 6.49 & -0.24 & 5.70 & -3.42 \\
\hline & $1995-2000$ & 1.33 & -0.89 & 0.44 & -0.82 & 0.17 \\
\hline
\end{tabular}


Figure 1

Trade balance

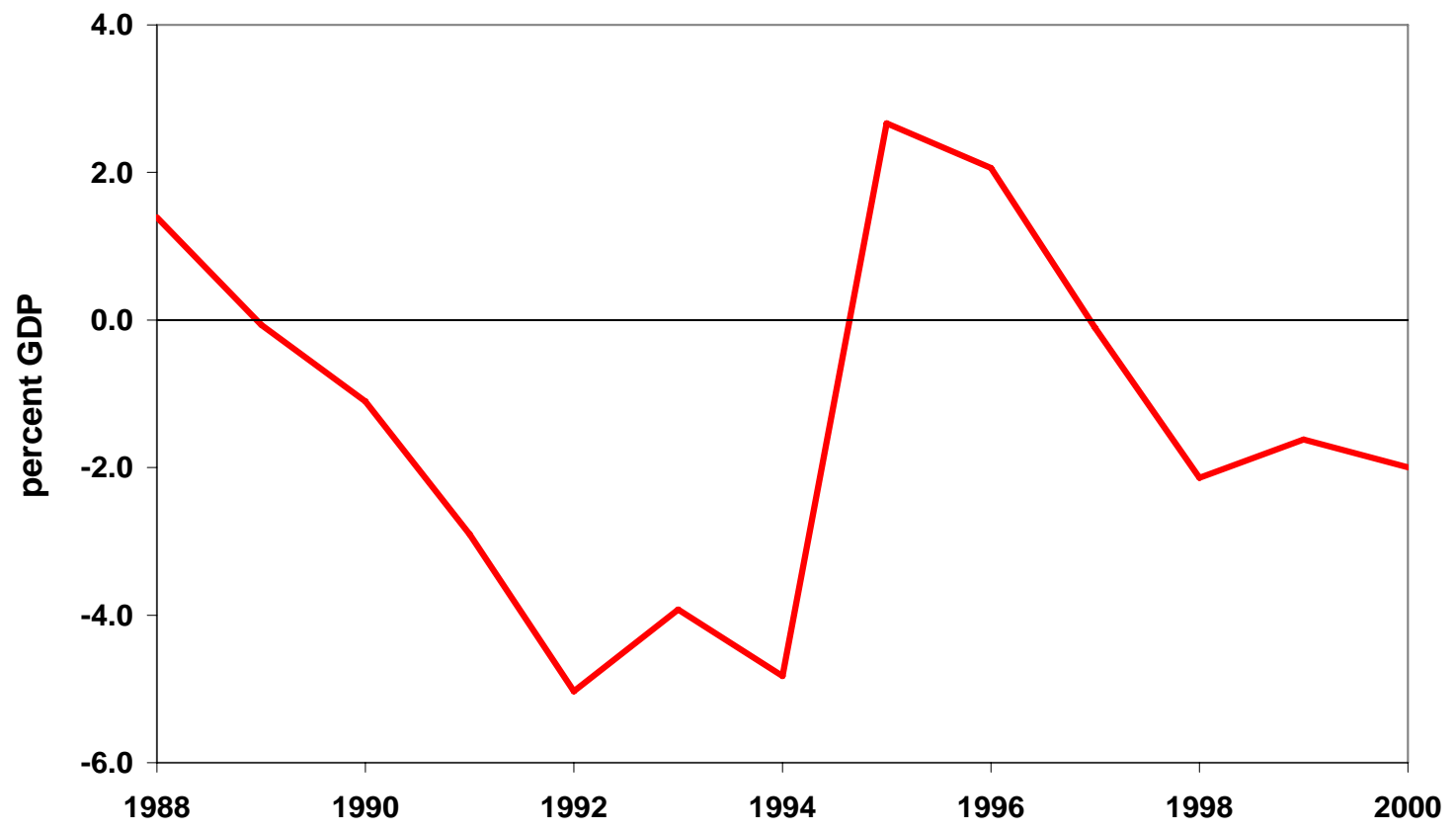

Figure 2

Real exchange rate

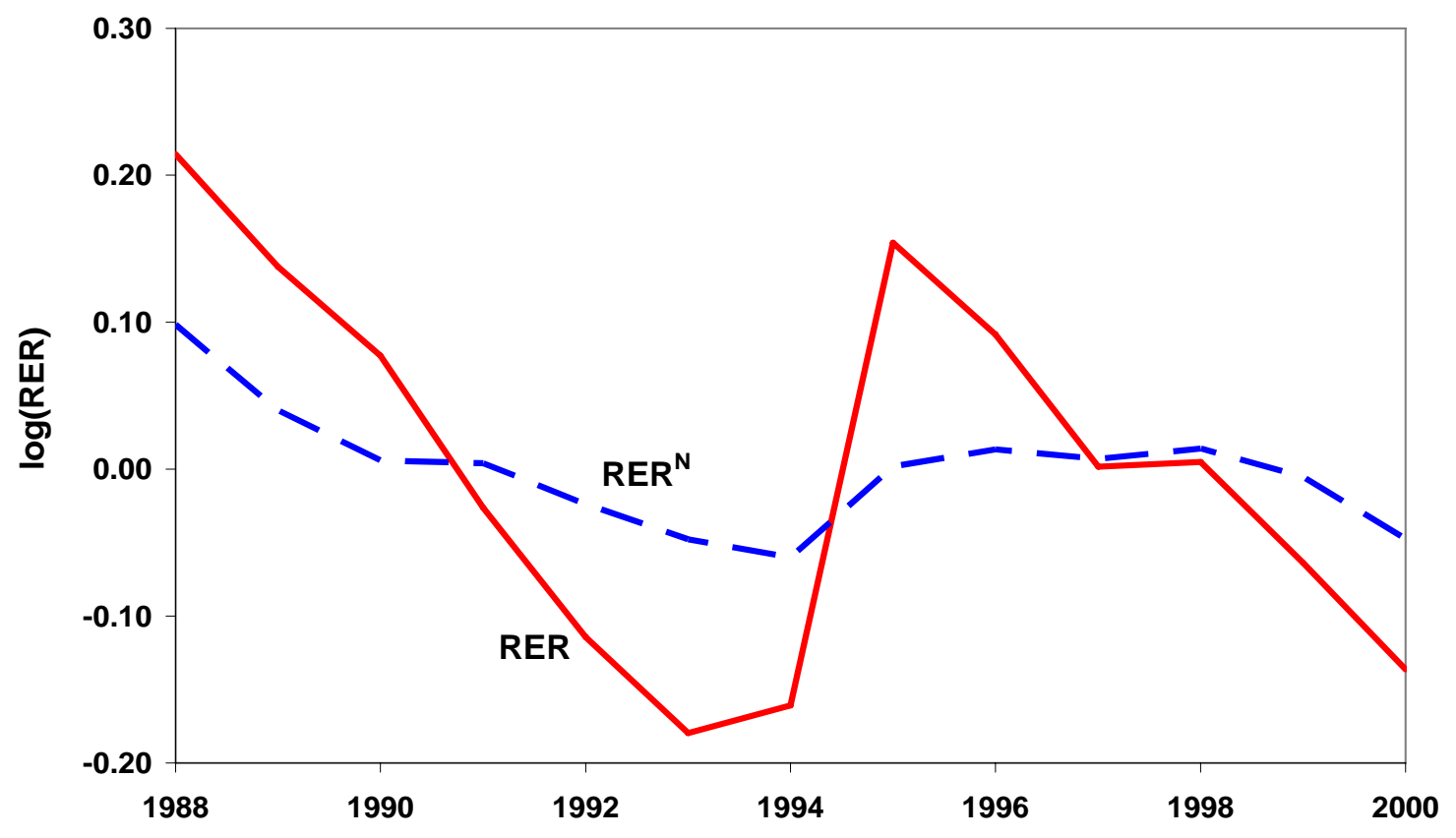


Figure 3

\section{Output and TFP}

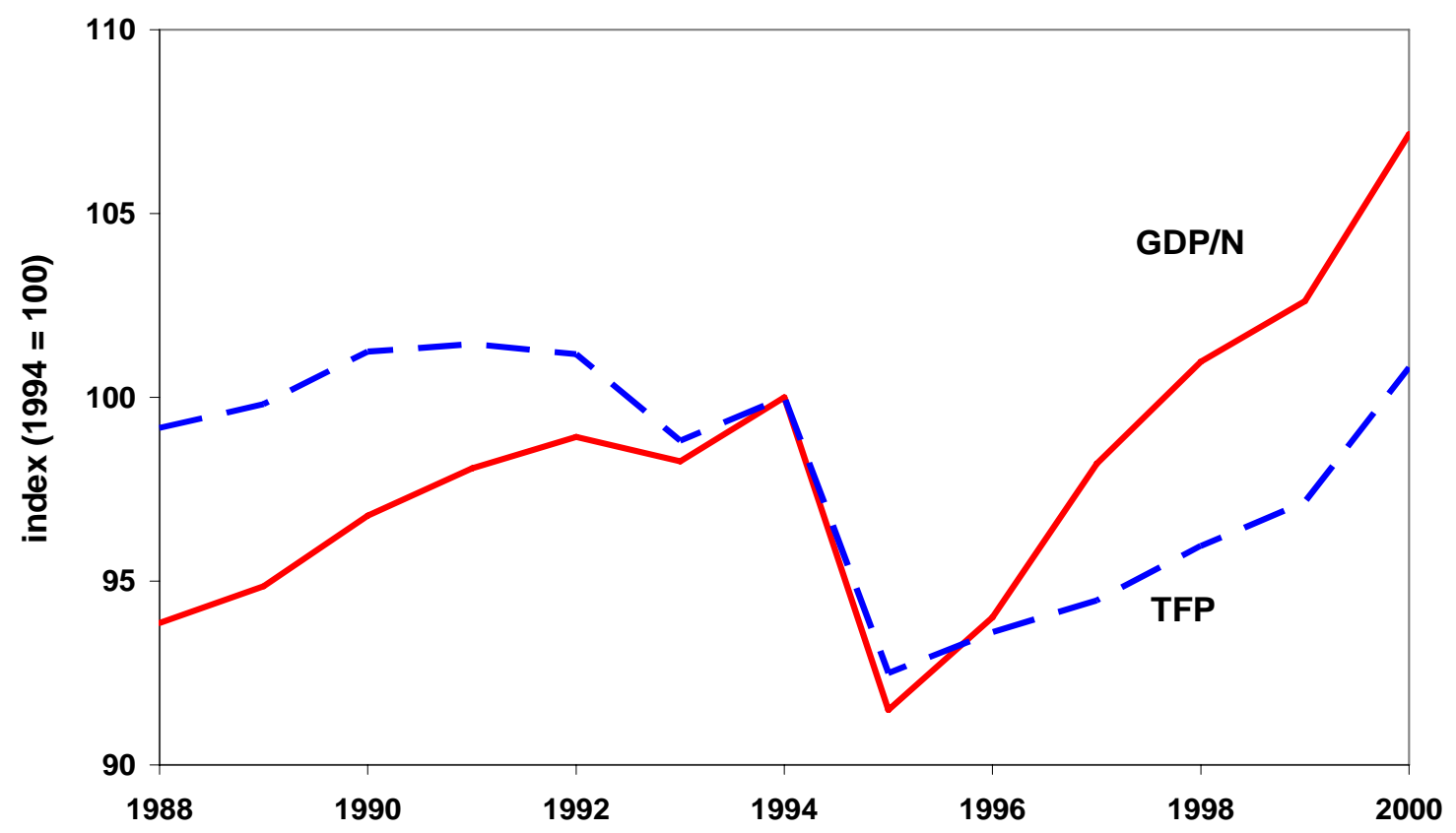

Figure 4

Value added by sector

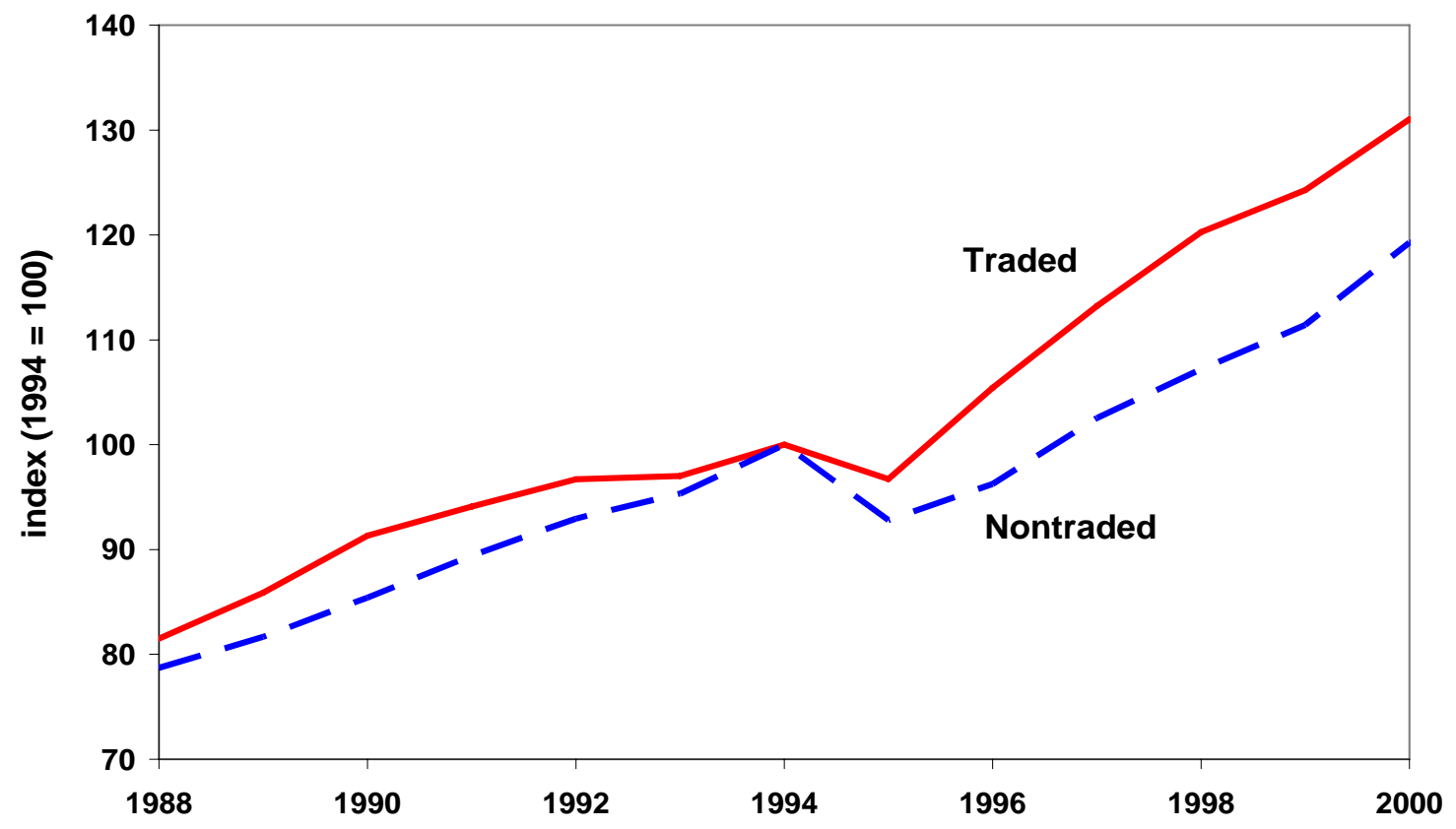


Figure 5

Interest rate premia

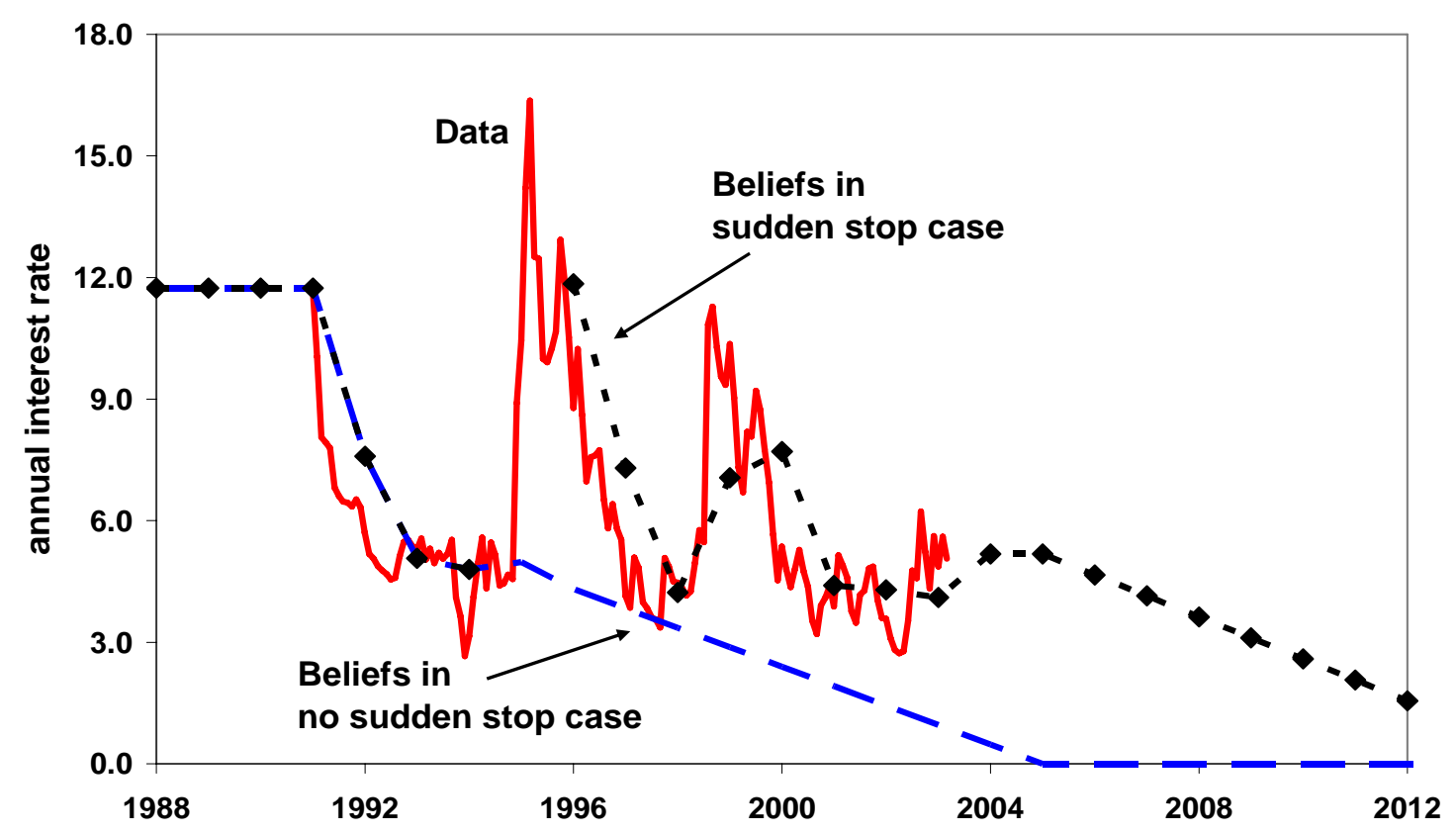

Figure 6

Model without sudden stop

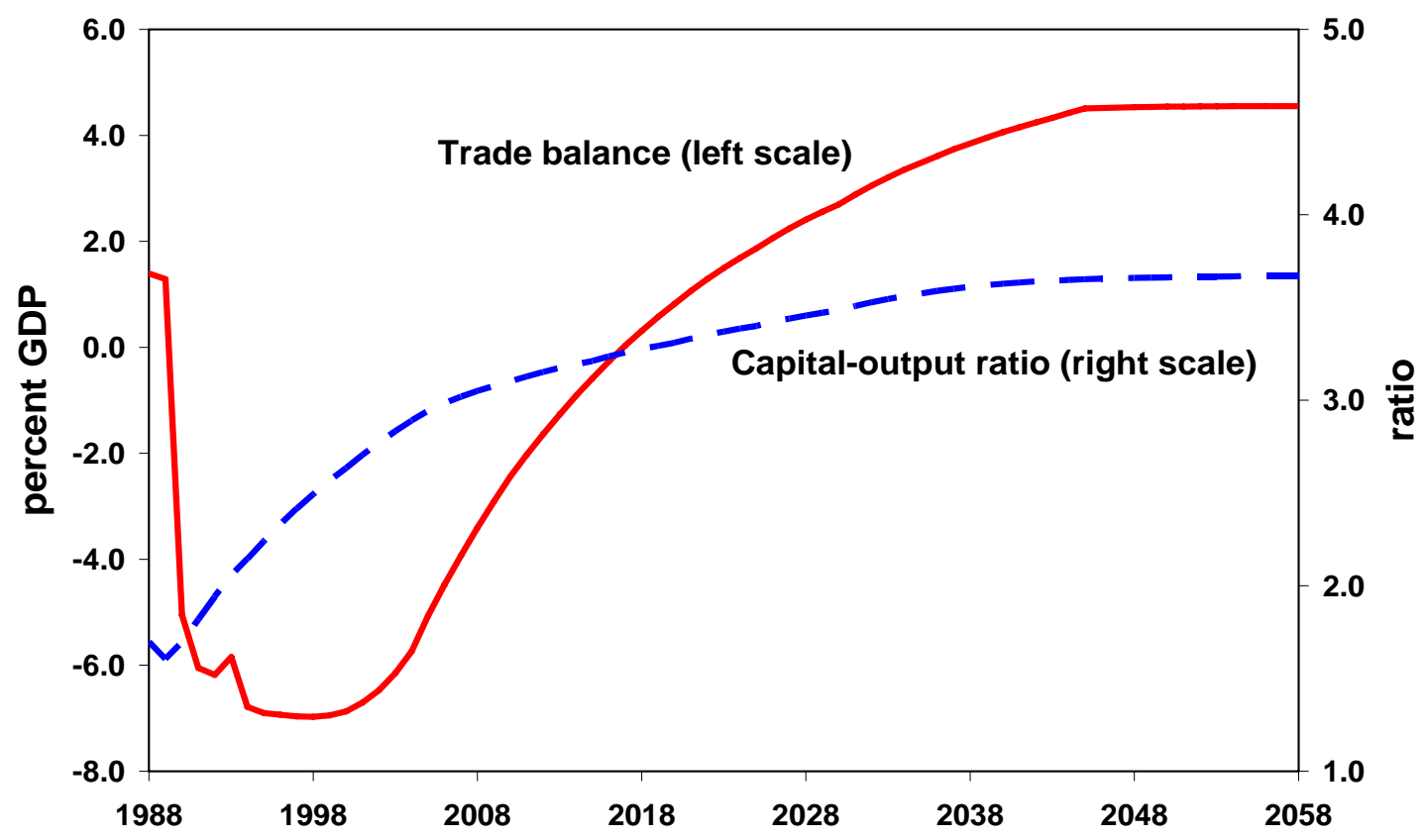


Figure 7

\section{Baseline model}

Trade balance

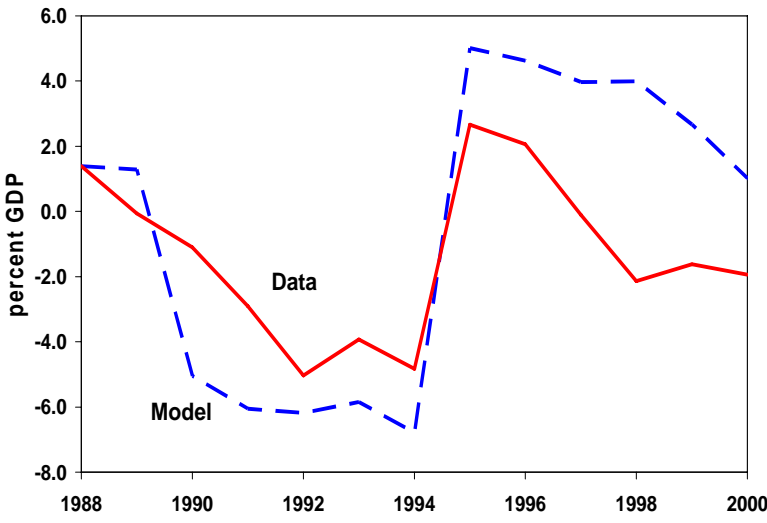

a.

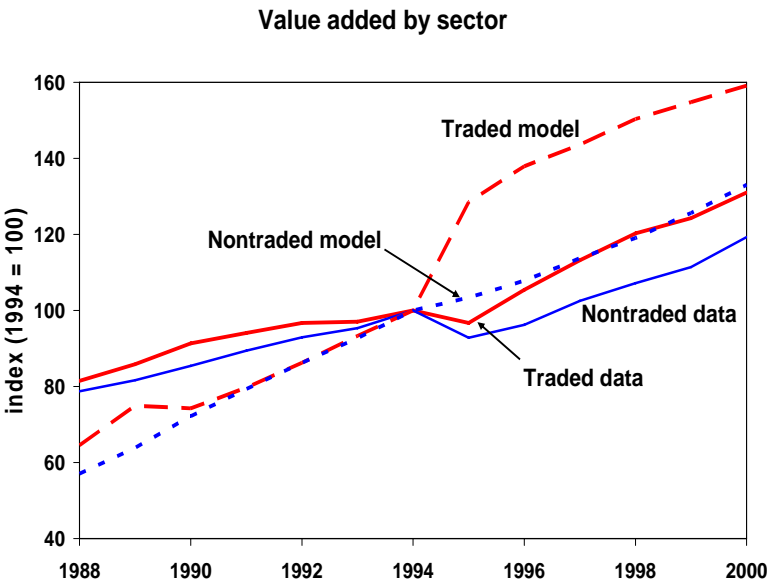

c.

Aggregate labor input

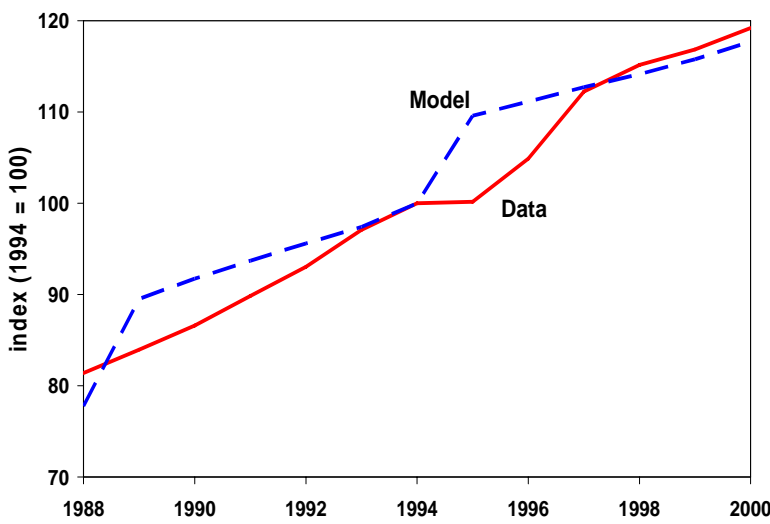

e.
Real exchange rate

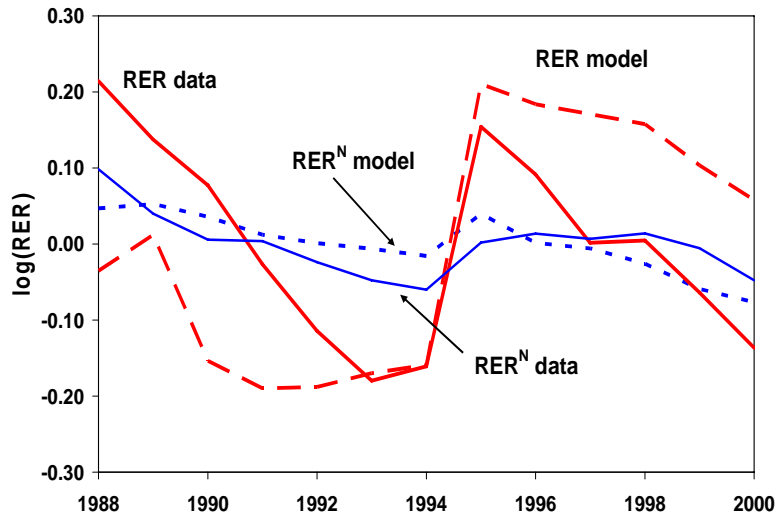

b.

Terms of trade

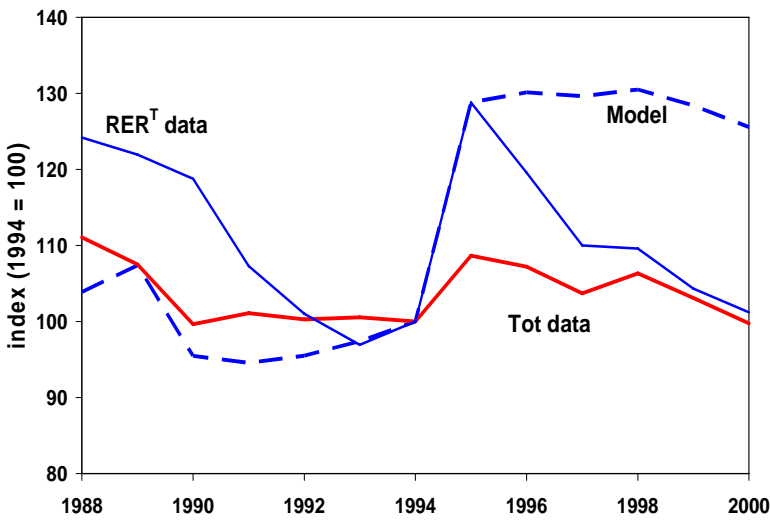

d.

Output and TFP

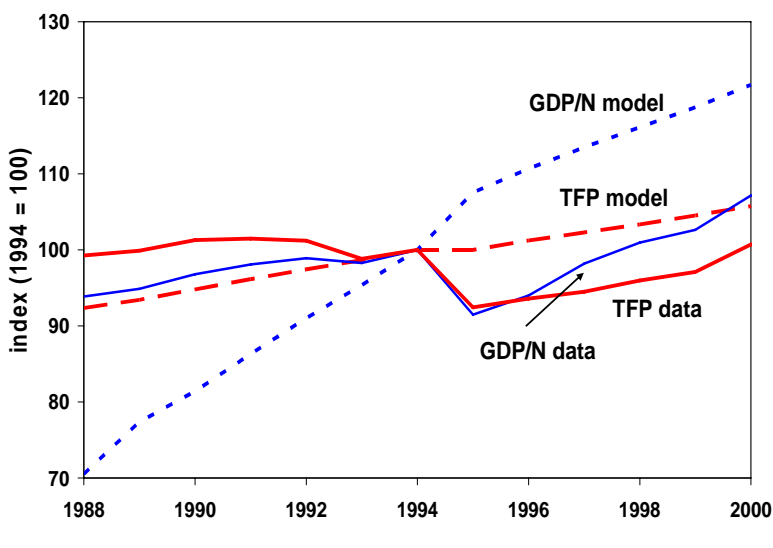

f. 
Figure 8

Model without interest premia

Trade balance

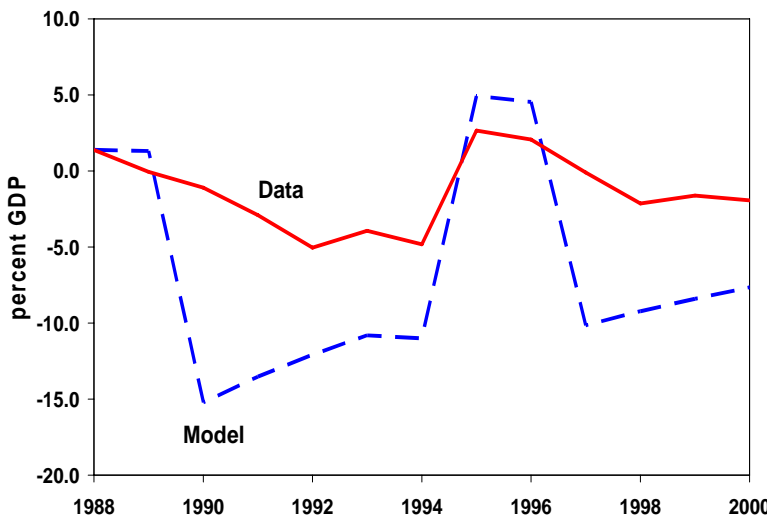

a.
Real exchange rate

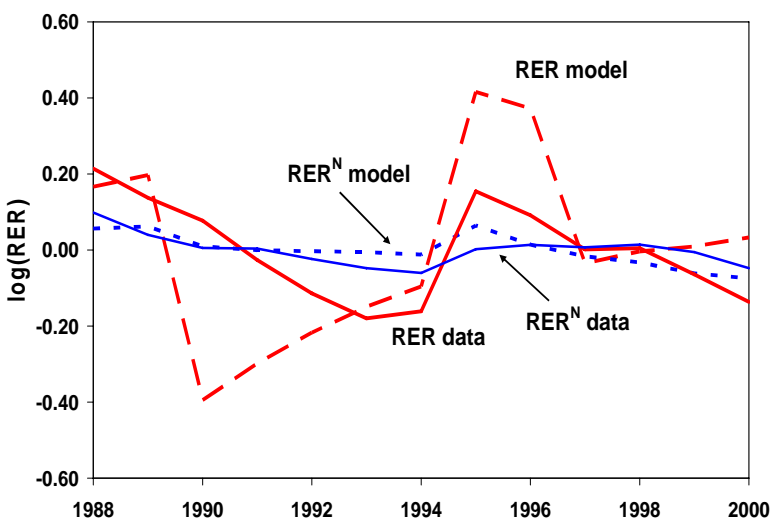

b.

Figure 9

Model without population growth

Trade balance

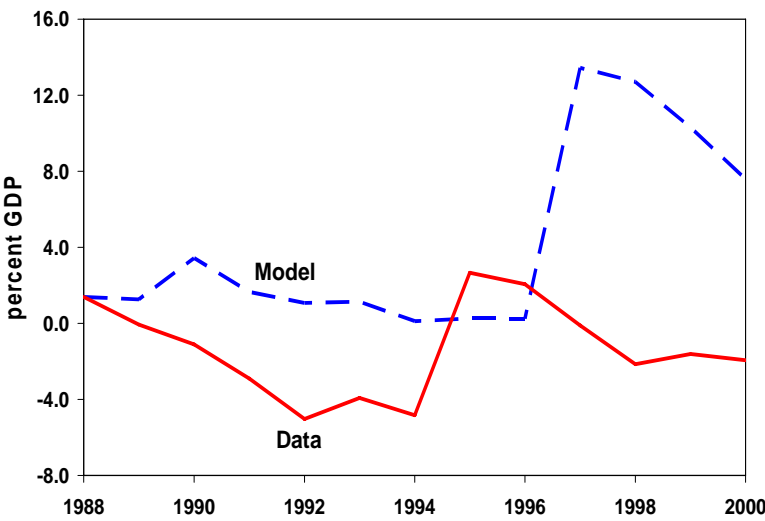

a.

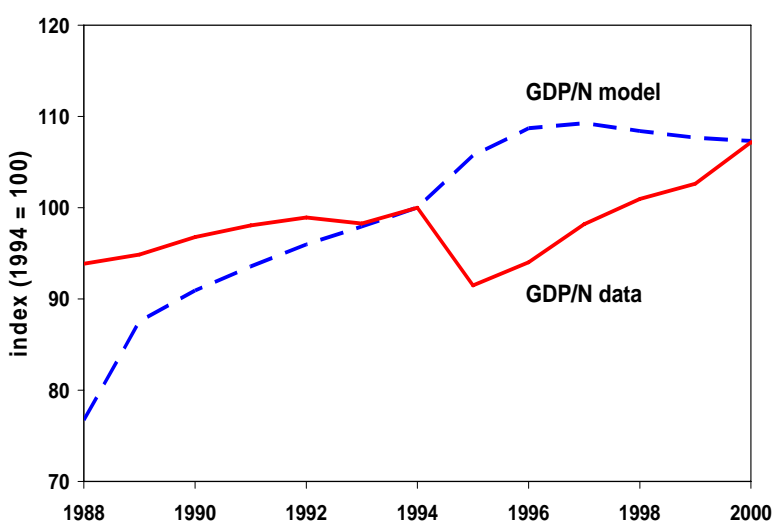

b.

Figure 10

Model with exogenous terms of trade

Terms of trade

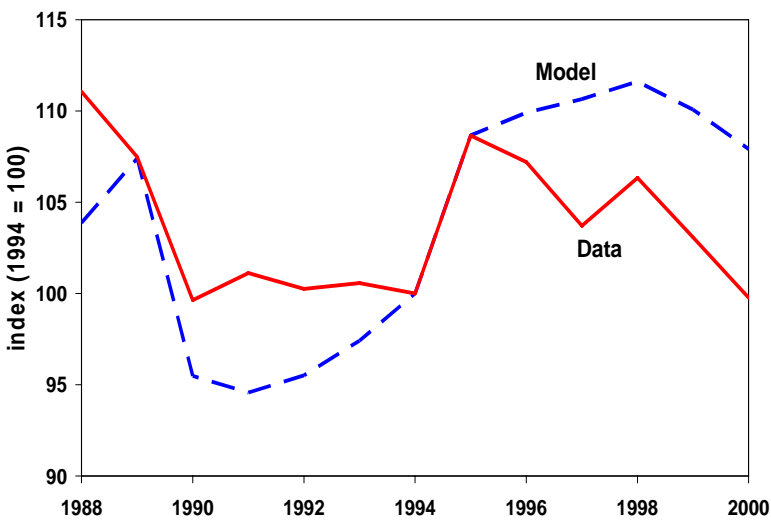

a.
Real exchange rate

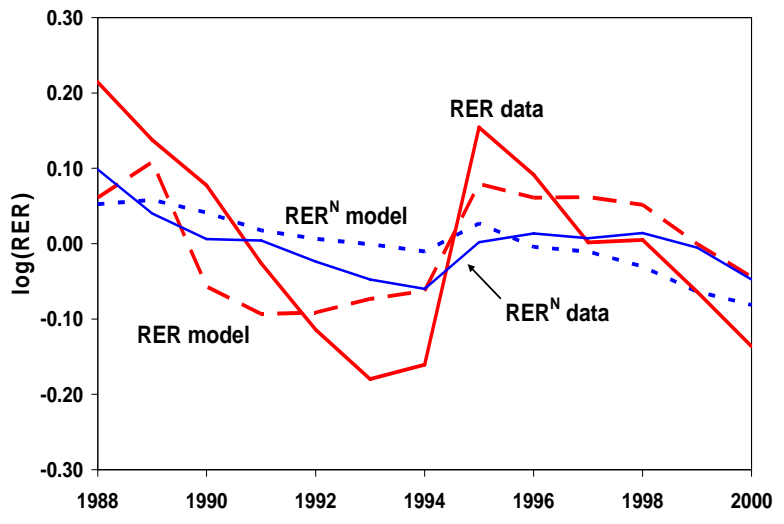

b. 
Figure 11

Model with labor frictions

Traded labor/total labor (detrended)

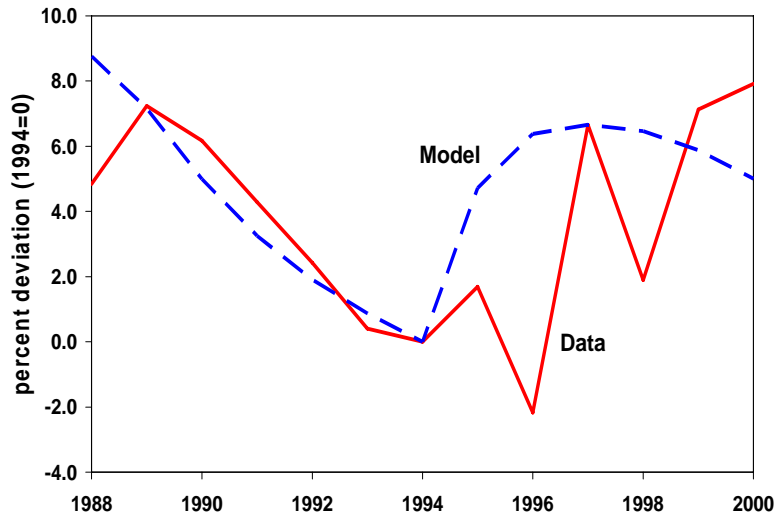

a.

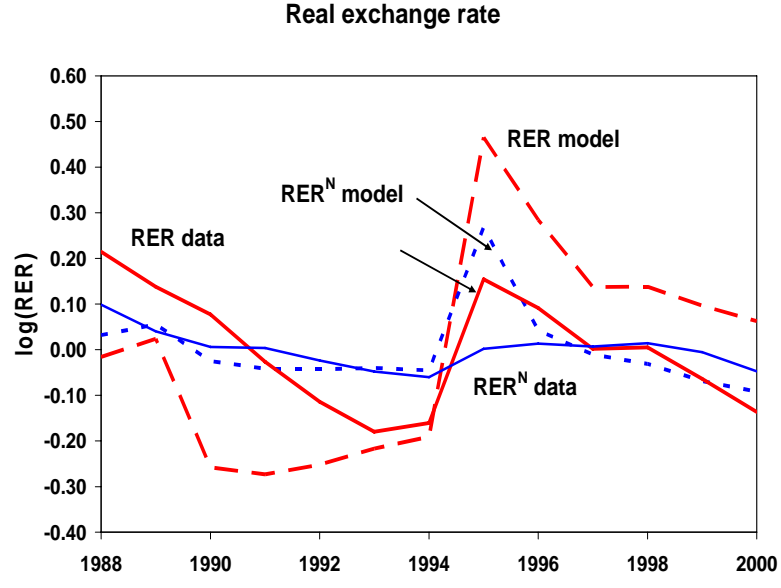

b.

Figure 12

Model with labor frictions and variable capital utilization

Output and TFP

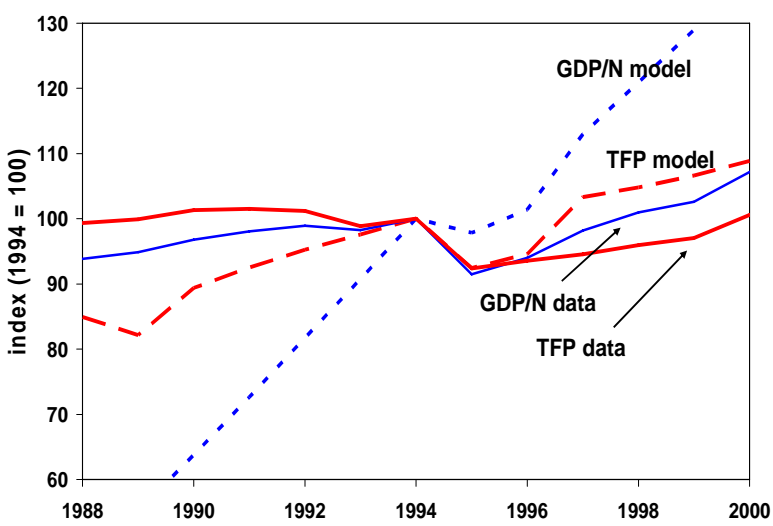

a.

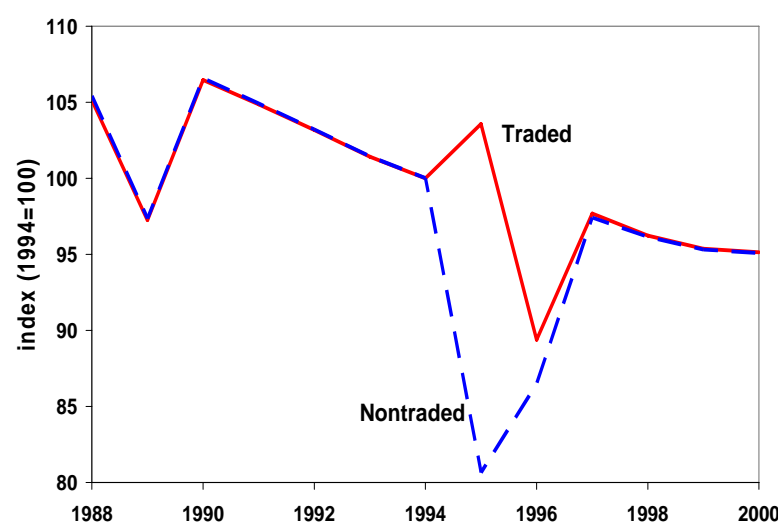

b.

Figure 13

Model with quasilinear utility and exogenous TFP

Aggregate labor input

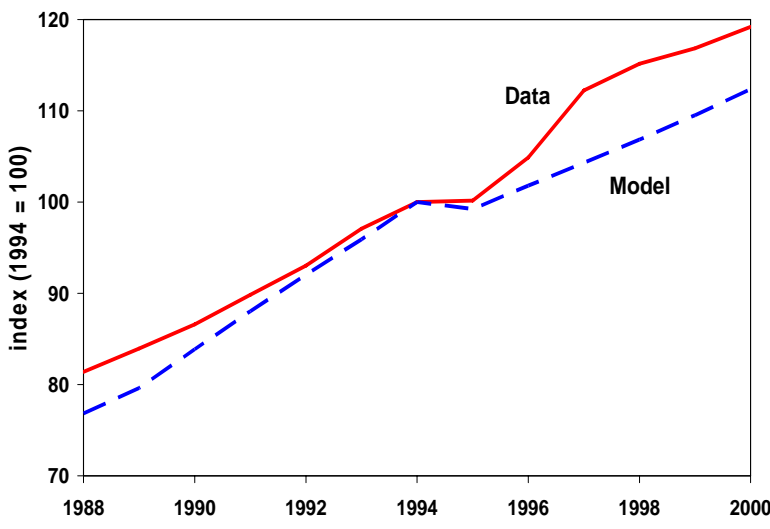

Output and TFP

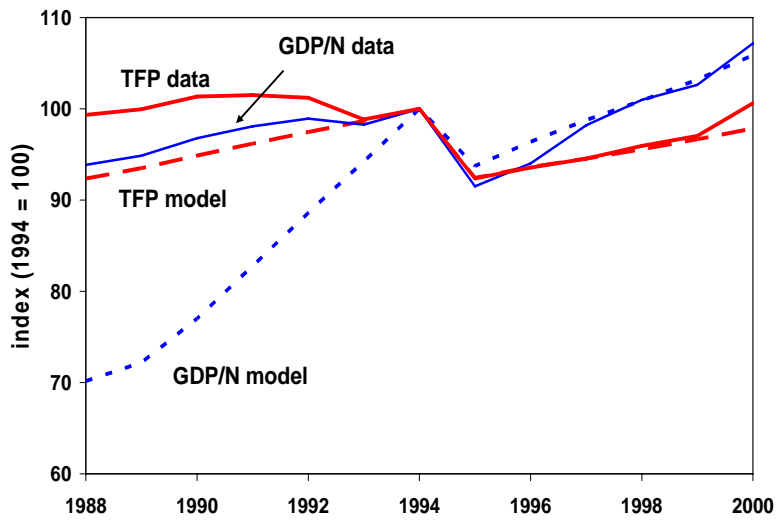

b. 